\title{
SPECTROSCOPIC, STRUCTURAL, THERMAL AND ANTIMICROBIAL STUDIES OF 4,6-BIS (4-CHLOROPHENYL)-2-OXO-1,2-DIHYDROPYRIDINE-3- CARBONITRILE WITH SOME TRANSITION METALS
}

\author{
S.A. Sadeek ${ }^{1 *}$, W.A. Zordok ${ }^{1}$, M.S. El-Attar ${ }^{1}$ and M.S. Ibrahim ${ }^{2}$ \\ ${ }^{1}$ Department of Chemistry, Faculty of Science, Zagazig University, Zagazig, Egypt \\ ${ }^{2}$ Alfa Miser for Industrial Investment, $10^{\text {th }}$ of Ramadan city, Egypt
}

(Received March 30, 2014; revised September 17, 2014)

\begin{abstract}
Bis(4-chlorophenyl)-2-oxo-1,2-dihydropyridine-3-carbonitrile (L) reacted with $\mathrm{Mn}$ (II), $\mathrm{Fe}(\mathrm{III}), \mathrm{Co}(\mathrm{II})$ and $\mathrm{Ni}(\mathrm{II})$ in methanol and acetone as a solvent at room temperature to form a new solid complexes. The isolated complexes were characterized by elemental analysis, magnetic properties, conductance measurements, mass, IR, UV-Vis and ${ }^{1} \mathrm{H}$ NMR spectroscopic methods and thermal analyses. The thermogravimetric and infrared spectroscopic data confirmed the presence of water in the composition of the complexes and the ligand reacted as a bidentate. The metal - ligand binding in metal complexes is predicted using density functional theory. The ligand and their metal complexes were also evaluated for their antibacterial activity. The complexes showed high activities compared with free ligand.
\end{abstract}

KEY WORDS: Pyridine derivative, 4,6-Bis(4-chlorophenyl)-2-oxo-1,2-dihydropyridine-3-carbonitrile, Transition metal complexes, Antibacterial activity

\section{INTRODUCTION}

In recent years the chemistry of heterocyclic compounds are well known for their diverse therapeutic properties and exhibited antibacterial, anticancer, antiulcer, diuretics, anticonvulsant, antihypertensive, antitumor, antifungal, anti-AIDS and antiviral properties [1].

Enones are excellent starting materials for the synthesis of 4,6-bis(4-chlorophenyl)-2-oxo1,2-dihydropyridine-3-carbonitrile (L) (Scheme 1) via the reaction of enone with ethyl cyanoacetate in the presence of ammonium acetate [2]. However, this procedure is time consuming and gives low yield. Jasinski et al. [2, 3] had reported an easy one-step synthesis which gives a higher yield of ligand by heating a mixture of 4-chloroacetophenone, 4chlorobenzaldehyde, ethyl cyanoacetate and ammonium acetate in presence of glacial acetic acid as a catalyst.

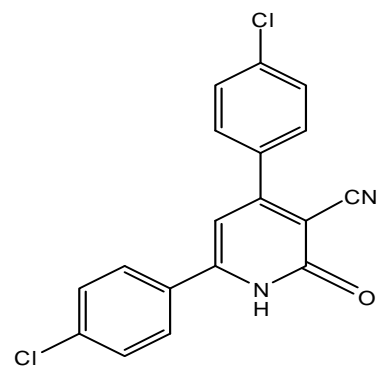

Scheme 1

Metal chelates play an important role in various fields of chemical, biological and technological sciences on coordination; ligands might improve their bioactivity profiles, while

*Corresponding author. E-mail: s_sadeek@zu.edu.eg 
some inactive ligand may acquire pharmacological properties. Activity of various antiinflammatory drugs existing in market has enhanced after complexation with transition metal ion [4].

A detailed literature research has showed that no work is reported on the 4,6-bis(4chlorophenyl)-2-oxo-1,2-dihydropyridine-3-carbonitrile (L). Thus, our aim was to synthesize and characterize the complexes of $\mathrm{Mn}(\mathrm{II}), \mathrm{Fe}(\mathrm{III}), \mathrm{Co}$ (II) and $\mathrm{Ni}(\mathrm{II})$ with $\mathrm{L}$ in order to investigate their magnetic, spectroscopic, thermal and antibacterial properties. Density functional theory (DFT) was used to compute the cation type influence on theoretical parameters of $\mathrm{Mn}(\mathrm{II}), \mathrm{Fe}(\mathrm{III}), \mathrm{Co}(\mathrm{II})$ and $\mathrm{Ni}(\mathrm{II})$ complexes of 4,6-bis-4-chlorophenyl-2-oxo-1,2dihydropyridine-3-carbonitrile and detect the exact structure of these complexes with different coordination numbers. Profiles of the optimal set and geometry of these complexes were simulated by applying the GAUSSIAN 98W package of programs [5] at B3LYP/CEP-31G [6] level of theory.

\section{EXPERIMENTAL}

\section{Reagents and solvents}

Reagent grade 4-chloroacetophenone, 4-benzaldehyde, ethyl cyanoacetate, ammonium acetate, glacial acetic acid, ethanol and acetone were purchased from Fluka Chemical Co. $\mathrm{MnSO}_{4} \cdot 6 \mathrm{H}_{2} \mathrm{O}$, $\mathrm{Fe}\left(\mathrm{NO}_{3}\right)_{3} \cdot 9 \mathrm{H}_{2} \mathrm{O}, \mathrm{CoCl}_{2} \cdot 6 \mathrm{H}_{2} \mathrm{O}$ and $\mathrm{NiSO}_{4} \cdot 8 \mathrm{H}_{2} \mathrm{O}$ from Aldrich Chemical Co. Solvents were purified by standard methods [7].

Preparation of 4,6-bis (4-chlorophenyl)-2-oxo-1,2-dihydropyridine-3-carbonitrile (L)

A mixture of 1,3-bis-(4-chloro-phenyl) propenone $(10 \mathrm{mmol})$, ethyl cyanoacetate $(10 \mathrm{mmol})$ and ammonium acetate $(80 \mathrm{mmol})$ in ethanol $(40 \mathrm{~mL})$ was refluxed in the presence of glacial acetic acid for $10 \mathrm{~h}$. After cooling, the precipitate was filtered off, dried and recrystallized from glacial acetic acid to give (L) [3].

\section{Preparation of the metal complexes}

The white solid complex $\left[\mathrm{Mn}(\mathrm{L})_{2}\left(\mathrm{H}_{2} \mathrm{O}\right)_{2}\right] \mathrm{SO}_{4}$ was prepared by adding $0.5 \mathrm{mmol}(0.129 \mathrm{~g})$ of manganese sulfate $\left(\mathrm{MnSO}_{4} \cdot 6 \mathrm{H}_{2} \mathrm{O}\right)$ in $20 \mathrm{~mL}$ ethanol drop-wise to a stirred suspended solution 1 mmol $(0.340 \mathrm{~g})$ of ligand $(\mathrm{L})$ in $50 \mathrm{~mL}$ ethanol. The reaction mixture was stirred for $15 \mathrm{~h}$ at 35 ${ }^{\circ} \mathrm{C}$ in water bath. The white precipitate was filtered off and dried under vacuum over anhydrous $\mathrm{CaCl}_{2}$. The light yellow, white and light green of $\left[\mathrm{Fe}(\mathrm{L})_{2}\left(\mathrm{H}_{2} \mathrm{O}\right)_{2}\right]\left(\mathrm{NO}_{3}\right)_{3},\left[\mathrm{Co}(\mathrm{L})_{2}\left(\mathrm{H}_{2} \mathrm{O}\right)_{2}\right] \mathrm{Cl}_{2}$ and $\left[\mathrm{Ni}(\mathrm{L})_{2}\left(\mathrm{H}_{2} \mathrm{O}\right)_{2}\right] \mathrm{SO}_{4} \cdot 6 \mathrm{H}_{2} \mathrm{O}$ were prepared in similar manner described above by using acetone as a solvent and using $\mathrm{Fe}\left(\mathrm{NO}_{3}\right)_{3} \cdot 9 \mathrm{H}_{2} \mathrm{O}, \mathrm{CoCl}_{2} \cdot 6 \mathrm{H}_{2} \mathrm{O}$ and $\mathrm{NiSO}_{4} \cdot 8 \mathrm{H}_{2} \mathrm{O}$, respectively, in 1:2 molar ratio.

Elemental $\mathrm{C}, \mathrm{H}$ and $\mathrm{N}$ analysis was carried out on a Perkin Elmer CHN 2400. The percentage of the metal ions were determined gravimetrically by transforming the solid products into metal oxide or sulphate and also determined by using atomic absorption method. Spectrometer model PYE-UNICAM SP 1900 fitted with the corresponding lamp was used for this purposed. IR spectra were recorded on FTIR 460 PLUS (KBr discs) in the range from 4000$400 \mathrm{~cm}^{-1}$. TGA-DTG measurements were carried out under $\mathrm{N}_{2}$ atmosphere within the temperature range from room temperature to $800{ }^{\circ} \mathrm{C}$ using TGA-50H Shimadzu thermal analyzer. Electronic spectra were obtained using UV-3101PC Shimadzu spectrophotometer. The solid reflection spectra were recorded with $\mathrm{KBr}$ pellets. Mass spectra were recorded on GCMSQP-2010 plus Shimadzu (ESI-70 eV). 
Magnetic measurements were carried out on a Sherwood scientific magnetic balance using Gouy method using $\mathrm{Hg}\left[\mathrm{Co}(\mathrm{SCN})_{4}\right]$ as calibrant. Molar conductivities of the solution of the ligand and metal complexes in DMF at $1 \times 10^{-3} \mathrm{M}$ were measured on CONSORT K410. All measurements were carried out at ambient temperature with freshly prepared solution.

\section{Antimicrobial investigation}

Antibacterial activity of the ligand and its metal complexes was investigated by a previously reported modified method of Beecher and Wong [8] against different bacterial species, such as Staphylococcus aureus, Bacillus subtilis, Escherichia coli and Pseudomonas aeruginosa and antifungal screening was studied against two species, Candida albicans and Aspergillus fumigatas. The tested microorganisms isolates were isolated from Egyptian soil and identified according to the standard mycological and bacteriological keys for identification of fungi and bacteria as stock cultures in the microbiology laboratory, Faculty of Science, Zagazig University. The nutrient agar medium for antibacterial was $(0.5 \%$ peptone, $0.1 \%$ beef extract, $0.2 \%$ yeast extract, $0.5 \% \mathrm{NaCl}$ and $1.5 \%$ agar-agar) and Czapek Dox media for antifungal (3\% sucrose, $0.3 \% \mathrm{NaNO}_{3}, 0.1 \% \mathrm{~K}_{2} \mathrm{HPO}_{4}, 0.05 \% \mathrm{KCl}, 0.001 \% \mathrm{FeSO}_{4}, 2 \%$ agar-agar) was prepared [9] and then cooled to $47{ }^{\circ} \mathrm{C}$ and seeded with tested microorganisms. Sterile water agar layer was poured, solidified then pour, the prepared growth medium for fungi and bacteria (plate of $12 \mathrm{~cm}$ diameter, $15 \mathrm{~mL}$ medium plate). After solidification $5 \mathrm{~mm}$ diameter holes were punched by a sterile cork-borer. The investigated compounds, i.e. ligand and their complexes, were introduced in Petri-dishes (only $0.1 \mathrm{~mL}$ ) after dissolving in DMF at $1.0 \times 10^{-3} \mathrm{M}$. These culture plates were then incubated at $37{ }^{\circ} \mathrm{C}$ for $20 \mathrm{~h}$ for bacteria and for seven days at $30{ }^{\circ} \mathrm{C}$ for fungi. The activity was determined by measuring the diameter of the inhibition zone (in $\mathrm{mm}$ ). Bacterial growth inhibition was calculated with reference to the positive control, i.e. ampicilin, amoxycillin and cefaloxin.

\section{RESULTS AND DISCUSSION}

4,6-Bis(4-chlorophenyl)-2-oxo-1,2-dihydropyridine-3-carbonitrile (L) complexes of $\mathrm{Mn}(\mathrm{II})$, $\mathrm{Fe}(\mathrm{III}), \mathrm{Co}(\mathrm{II})$ and $\mathrm{Ni}(\mathrm{II})$ were obtained in moderate good yields $(68-78 \%)$ as solids of a color characteristics of the metal ion. Single crystals suitable for X-ray crystallographic measurements were not obtained. Table 1 summarizes the carbon, hydrogen and nitrogen elemental analysis as well as melting points and magnetic properties of the isolated solid complexes. The results obtained indicated that all of the isolated complexes are formed from the reaction of the metal salts with L in 1:2 molar ratios. All of the complexes reported here in are hydrates with various degrees of hydration and air stable solids at room temperature. Elemental analyses of C, H, N, S and $\mathrm{M}(\mathrm{M}=\mathrm{Mn}, \mathrm{Fe}, \mathrm{Co}$ or $\mathrm{Ni})$ are in accordance with the proposed compositions of the complexes. The molar conductivities at room temperature in DMF solvent at $1.0 \times 10^{-3} \mathrm{M}$ of free ligand (L) and their metal complexes were in the range 15.9 to $230.6 \mathrm{~S} \mathrm{~cm}^{2} \mathrm{~mol}^{-1}$ which indicated that the complexes were electrolyte in the solvent with three categories [10]. Conductivity measurements have frequently been used to predicts the structure of metal chelates within the limits of their solubility. They provide a method of testing the degree of ionization of the complexes. It is clear from the conductivity data that the complexes are electrolytes. The obtained results were strongly matched with experimental data which indicated that sulfate, chloride and nitrate groups are found as counter ions (outside the complexes sphere). The magnetic moments (as B.M.) of the complexes were measured at room temperature. The Mn(II), $\mathrm{Fe}(\mathrm{III}), \mathrm{Co}(\mathrm{II})$ and $\mathrm{Ni}(\mathrm{II})$ complexes are found in paramagnetism character and octahedral geometry (high spin) around the metal ion with measured magnetic moment values at 5.81, 5.62, 3.72 and 2.73 B.M., respectively. 
Table 1. Elemental analysis and physico-analytical data for (L) ligand and its metal complexes.

\begin{tabular}{|c|c|c|c|c|c|c|c|c|c|c|}
\hline \multirow{2}{*}{$\begin{array}{l}\text { Compounds } \\
\text { M.Wt. (M.F.) }\end{array}$} & \multirow{2}{*}{$\begin{array}{c}\text { Yield } \\
\%\end{array}$} & \multirow{2}{*}{$\begin{array}{c}\mathrm{Mp} \\
{ }^{\circ} \mathrm{C}\end{array}$} & \multirow{2}{*}{ Color } & \multicolumn{5}{|c|}{ Found (calcd.) (\%) } & \multirow[t]{2}{*}{$\mu_{\text {eff }}$ (B.M.) } & \multirow{2}{*}{$\begin{array}{c}\Lambda \\
\mathrm{S} \mathrm{cm}^{2} \\
\mathrm{~mol}^{-1}\end{array}$} \\
\hline & & & & C & $\mathrm{H}$ & $\mathrm{N}$ & $\mathrm{M}$ & $\mathrm{S}$ & & \\
\hline $\begin{array}{c}(\mathrm{L}) \\
341\left(\mathrm{C}_{18} \mathrm{H}_{10} \mathrm{~N}_{2} \mathrm{OCl}_{2}\right)\end{array}$ & 80.0 & 298 & White & $\begin{array}{c}(63.33) \\
63.34 \\
\end{array}$ & $\begin{array}{c}(2.91) \\
2.93 \\
\end{array}$ & \begin{tabular}{|c|}
$(8.20)$ \\
8.21
\end{tabular} & & & Diamagnetic & 15.9 \\
\hline $\begin{array}{c}{\left[\mathrm{Mn}(\mathrm{L})_{2}\left(\mathrm{H}_{2} \mathrm{O}\right)_{2}\right] \mathrm{SO}_{4}} \\
868.93 \\
\left(\mathrm{C}_{36} \mathrm{H}_{24} \mathrm{~N}_{4} \mathrm{O}_{8} \mathrm{Cl}_{4} \mathrm{SMn}\right)\end{array}$ & 68.5 & 300 & White & $\begin{array}{c}(49.69) \\
49.71\end{array}$ & \begin{tabular}{|c|}
$(2.66)$ \\
2.67
\end{tabular} & \begin{tabular}{|c|}
$(6.42)$ \\
6.44
\end{tabular} & $\begin{array}{c}(6.32) \\
6.33\end{array}$ & $\begin{array}{c}(3.67) \\
3.68\end{array}$ & 5.81 & 190.6 \\
\hline $\begin{array}{c}{\left[\mathrm{Fe}(\mathrm{L})_{2}\left(\mathrm{H}_{2} \mathrm{O}\right)_{2}\right]\left(\mathrm{NO}_{3}\right)_{3}} \\
959.8 \\
\left(\mathrm{C}_{36} \mathrm{H}_{24} \mathrm{~N}_{7} \mathrm{O}_{13} \mathrm{Cl}_{4} \mathrm{Fe}\right)\end{array}$ & 73.3 & 288 & $\begin{array}{c}\text { Light } \\
\text { yellow }\end{array}$ & $\begin{array}{c}(44.98) \\
45.00\end{array}$ & $\begin{array}{c}(2.49) \\
2.50\end{array}$ & $\begin{array}{c}(10.20) \\
10.21\end{array}$ & $\begin{array}{c}(4.99) \\
4.92\end{array}$ & & 5.62 & 230.6 \\
\hline $\begin{array}{c}{\left[\mathrm{Co}(\mathrm{L})_{2}\left(\mathrm{H}_{2} \mathrm{O}\right)_{2}\right] \mathrm{Cl}_{2}} \\
846.9 \\
\left(\mathrm{C}_{36} \mathrm{H}_{28} \mathrm{~N}_{4} \mathrm{O}_{6} \mathrm{Cl}_{6} \mathrm{Co}\right) \\
\end{array}$ & \begin{tabular}{|l|}
69.8 \\
\end{tabular} & 310 & White & $\begin{array}{c}(49.55) \\
51.00\end{array}$ & $\begin{array}{c}(3.27) \\
3.30\end{array}$ & $\begin{array}{c}(6.54) \\
6.61\end{array}$ & $\begin{array}{l}(6.90) \\
6.95\end{array}$ & & 3.72 & 218.8 \\
\hline $\begin{array}{c}\left.\mathrm{Ni}(\mathrm{L})_{2}\left(\mathrm{H}_{2} \mathrm{O}\right)_{2}\right] \mathrm{SO}_{4} \cdot 6 \mathrm{H}_{2} \mathrm{O} \\
980.8 \\
\left(\mathrm{C}_{36} \mathrm{H}_{30} \mathrm{~N}_{4} \mathrm{O}_{11} \mathrm{Cl}_{4} \mathrm{SNi}\right)\end{array}$ & \begin{tabular}{|l|}
78.7 \\
\end{tabular} & $>360$ & \begin{tabular}{|l|} 
Light \\
green
\end{tabular} & $\begin{array}{c}(43.95) \\
44.04\end{array}$ & $\begin{array}{c}(3.00) \\
3.05\end{array}$ & \begin{tabular}{|c|}
$(5.58)$ \\
5.70
\end{tabular} & $\begin{array}{c}(5.95) \\
5.98\end{array}$ & $\begin{array}{c}(3.22) \\
3.26\end{array}$ & 2.73 & 185 \\
\hline
\end{tabular}

IR absorption spectra

The mid infrared spectra of $\left[\mathrm{Mn}(\mathrm{L})_{2}\left(\mathrm{H}_{2} \mathrm{O}\right)_{2}\right] \mathrm{SO}_{4},\left[\mathrm{Fe}(\mathrm{L})_{2}\left(\mathrm{H}_{2} \mathrm{O}\right)_{2}\right]\left(\mathrm{NO}_{3}\right)_{3},\left[\mathrm{Co}(\mathrm{L})_{2}\left(\mathrm{H}_{2} \mathrm{O}\right)_{2}\right] \mathrm{Cl}_{2}$, $\left[\mathrm{Ni}(\mathrm{L})_{2}\left(\mathrm{H}_{2} \mathrm{O}\right)_{2}\right] \mathrm{SO}_{4} \cdot 6 \mathrm{H}_{2} \mathrm{O}$ and $\mathrm{L}$ were measured as $\mathrm{KBr}$ discs (Figure 1). The proposed structure for all complexes is represented by Scheme 2

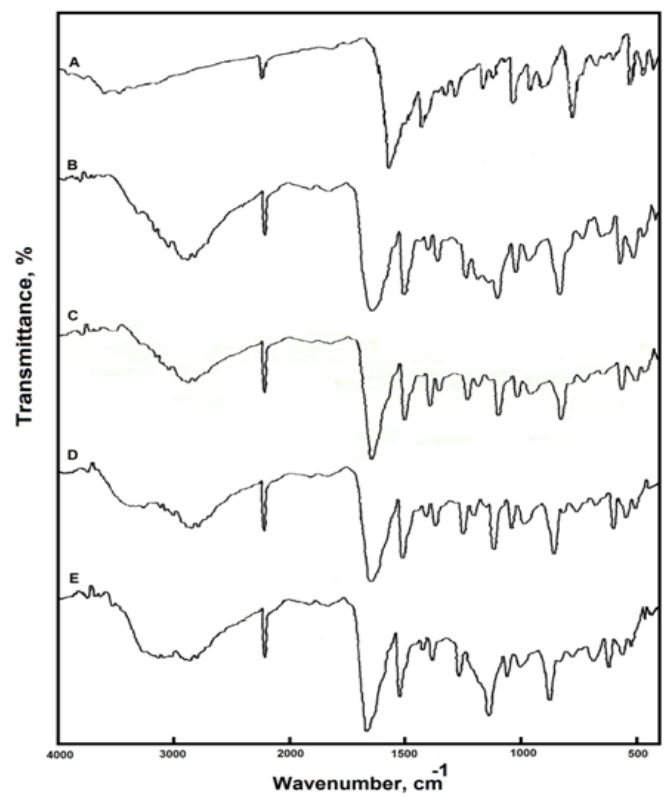

Figure 1. Infrared spectra for (A) (L), (B) $\left[\mathrm{Mn}(\mathrm{L})_{2}\left(\mathrm{H}_{2} \mathrm{O}\right)_{2}\right] \mathrm{SO}_{4},(\mathrm{C})\left[\mathrm{Fe}(\mathrm{L})_{2}\left(\mathrm{H}_{2} \mathrm{O}\right)_{2}\right]\left(\mathrm{NO}_{3}\right)_{3}$, (D) $\left[\mathrm{Co}(\mathrm{L})_{2}\left(\mathrm{H}_{2} \mathrm{O}\right)_{2}\right] \mathrm{Cl}_{2}$ and $(\mathrm{E})\left[\mathrm{Ni}(\mathrm{L})_{2}\left(\mathrm{H}_{2} \mathrm{O}\right)_{2}\right] \mathrm{SO}_{4} \cdot 6 \mathrm{H}_{2} \mathrm{O}$. 


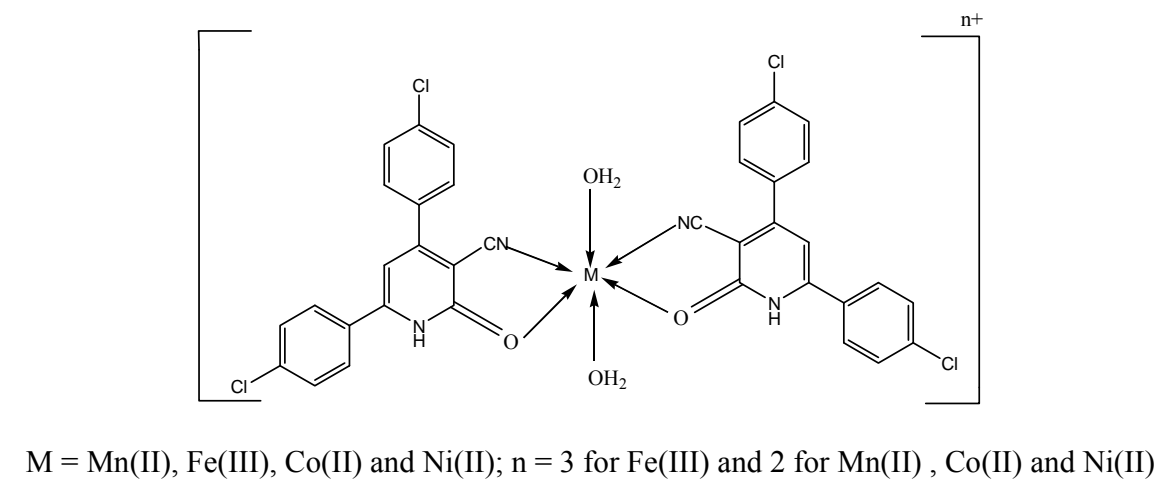

Scheme 2. The coordination mode of $\mathrm{M}$ with $\mathrm{L}$.

The four donor atoms of the two ligands (L) coordinated to central metal ions equatorially in a plane forming tetragon with the two oxygen atoms of the two coordinated water molecules axial. According to the proposed structure for the complexes under investigation, the complexes possess a two-fold axis and two planes of symmetry and hence they are $\mathrm{C}_{2 v}$ symmetry. The $\mathrm{C}_{2 v}$ complexes, $\left[\mathrm{M}(\mathrm{L})_{2}\left(\mathrm{H}_{2} \mathrm{O}\right)_{2}\right]^{\mathrm{n}+}$ are expected to display 213 vibrational fundamentals which all are monodegenerate and distributed between $\mathrm{A}_{1}, \mathrm{~A}_{2}, \mathrm{~B}_{1}$ and $\mathrm{B}_{2}$ motions; all are IR and Raman active, except $\mathrm{A}_{2}$ modes which are only Raman active.

The infrared spectrum of free ligand (L) shows two bands at 2215 and $1628 \mathrm{~cm}^{-1}$ (Table 2) which are attributed to the stretching vibration of $v(\mathrm{C} \equiv \mathrm{N})$ for carbonitrile group and $v(\mathrm{C}=\mathrm{O})$ keto group $[11,12]$. Upon comparison of the IR spectra of the complexes with that of free ligand the change in intensity of $v(\mathrm{C} \equiv \mathrm{N})$ from medium to strong (Table 2) confirming that the $\mathrm{L}$ molecule coordinated to metal ion through carbonitrile nitrogen. Also, the shift of $v(C=O)$ to higher frequency value $\left(1636 \mathrm{~cm}^{-1}\right)$ in the spectra of the complexes may indicate an increase of the $\mathrm{C}=\mathrm{O}$ bond strength upon coordination. The possibility that the electron density on the oxygen atom is decrease upon coordination to metals means decrease in the electron repulsion between the oxygen lone pair and the double bond electrons leading to a stronger $\mathrm{C}=\mathrm{O}$ bond and then a higher bond frequency. The increase of $v(\mathrm{C}=\mathrm{O})$ frequency upon coordination was reported by the other workers in the spectra of other complexes $[13,14]$. These changes of the IR spectra suggest that the free ligand is coordinated to the metal ions via oxygen of keto group and nitrogen of carbonitrile group.

The bands in the range $3533-3378 \mathrm{~cm}^{-1}$ in the spectra of the complexes can be attributed to the $v(\mathrm{O}-\mathrm{H})$ vibration of the water molecules [15]. The $v(\mathrm{~N}-\mathrm{H})$ vibration appears in the region of $3289-3267 \mathrm{~cm}^{-1}$ and the stretching vibrations $v(\mathrm{C}-\mathrm{H})$ of phenyl groups are assigned as a number of bands in the region $3136-3017 \mathrm{~cm}^{-1}$ [16].

The spectra of the isolated solid complexes showed a group of new bands with different intensities which characteristics for $v(\mathrm{M}-\mathrm{O})$ and $v(\mathrm{M}-\mathrm{N})$. The $v(\mathrm{M}-\mathrm{O})$ band observed at 622 , 620,622 and $633 \mathrm{~cm}^{-1}$ for $\mathrm{Mn}(\mathrm{II}), \mathrm{Fe}(\mathrm{III}), \mathrm{Co}(\mathrm{II})$ and $\mathrm{Ni}(\mathrm{II})$, respectively and $v(\mathrm{M}-\mathrm{N})$ found at $467 \mathrm{~cm}^{-1}$ with different intensities for $\mathrm{Mn}(\mathrm{II}), \mathrm{Fe}(\mathrm{III}), \mathrm{Co}(\mathrm{II})$ and $\mathrm{Ni}(\mathrm{II})$ complexes indicating coordination of metal ion to ketonic oxygen and carbonitrile nitrogen atoms [17]. 
Table 2. Infrared frequencies $\left(\mathrm{cm}^{-1}\right)$ and tentative assignments for (A) $\mathrm{L},(\mathrm{B})\left[\mathrm{Mn}(\mathrm{L})_{2}\left(\mathrm{H}_{2} \mathrm{O}\right)_{2}\right] \mathrm{SO}_{4},(\mathrm{C})$ $\left[\mathrm{Fe}(\mathrm{L})_{2}\left(\mathrm{H}_{2} \mathrm{O}\right)_{2}\right]\left(\mathrm{NO}_{3}\right)_{3},(\mathrm{D})\left[\mathrm{Co}(\mathrm{L})_{2}\left(\mathrm{H}_{2} \mathrm{O}\right)_{2}\right] \mathrm{Cl}_{2} \cdot 2 \mathrm{H}_{2} \mathrm{O}$ and $(\mathrm{E})\left[\mathrm{Ni}(\mathrm{L})_{2}\left(\mathrm{H}_{2} \mathrm{O}\right)_{2}\right] \mathrm{SO}_{4} \cdot 6 \mathrm{H}_{2} \mathrm{O}$.

\begin{tabular}{|c|c|c|c|c|c|}
\hline $\mathrm{A}$ & $\mathrm{B}$ & $\mathrm{C}$ & $\mathrm{D}$ & $\mathrm{E}$ & Assignments \\
\hline & $3533 \mathrm{mbr}$ & $3444 \mathrm{mbr}$ & $3378 \mathrm{mbr}$ & $3466 \mathrm{mbr}$ & $v \mathrm{H}_{2} \mathrm{O}$ \\
\hline $3278 \mathrm{w}$ & $3289 \mathrm{w}$ & $3289 \mathrm{sh}$ & $3283 \mathrm{w}$ & $3267 \mathrm{sh}$ & $v(\mathrm{~N}-\mathrm{H})$ \\
\hline $3130 \mathrm{w}$ & $3133 \mathrm{w}$ & $3133 \mathrm{w}$ & $3133 \mathrm{sh}$ & $3136 \mathrm{sh}$ & $v(\mathrm{C}-\mathrm{H})$; aromatic \\
\hline $3088 \mathrm{w}$ & $3089 \mathrm{vw}$ & $3089 \mathrm{sh}$ & $3089 \mathrm{sh}$ & $3111 \mathrm{sh}$ & \\
\hline $3017 \mathrm{w}$ & $3020 \mathrm{w}$ & $3020 \mathrm{w}$ & $3020 \mathrm{w}$ & $3024 \mathrm{sh}$ & \\
\hline $2215 \mathrm{~m}$ & $2214 \mathrm{~s}$ & $2214 \mathrm{~s}$ & $2214 \mathrm{~s}$ & $2214 \mathrm{~s}$ & $v(\mathrm{C} \equiv \mathrm{N})$ \\
\hline $1628 \mathrm{~s}$ & 1634 vs & $1634 \mathrm{vs}$ & $1634 \mathrm{vs}$ & $1634 \mathrm{vs}$ & $v(\mathrm{C}=\mathrm{O})$ \\
\hline $1566 \mathrm{sh}$ & $1545 \mathrm{sh}$ & $1545 \mathrm{sh}$ & $1545 \mathrm{sh}$ & $1544 \mathrm{sh}$ & $v(\mathrm{C}=\mathrm{C}) ;$ and phenyl \\
\hline $1491 \mathrm{~ms}$ & $1493 \mathrm{~s}$ & $1493 \mathrm{~s}$ & $1489 \mathrm{~s}$ & $1493 \mathrm{~s}$ & breathing modes and \\
\hline $1423 \mathrm{vw}$ & $1422 \mathrm{w}$ & $1422 \mathrm{sh}$ & $1433 \mathrm{sh}$ & $1433 \mathrm{sh}$ & $v_{\mathrm{as}}(\mathrm{N}-\mathrm{O}) ; \mathrm{NO}_{3}$ \\
\hline $1390 \mathrm{w}$ & $1389 \mathrm{~m}$ & $1385 \mathrm{~m}$ & 1389 w & $1389 \mathrm{w}$ & \\
\hline $1346 \mathrm{~m}$ & $1346 \mathrm{~ms}$ & $1346 \mathrm{w}$ & $1346 \mathrm{~m}$ & $1346 \mathrm{~m}$ & \\
\hline $1223 \mathrm{~m}$ & $1223 \mathrm{~ms}$ & $1223 \mathrm{~m}$ & $1223 \mathrm{~m}$ & $1123 \mathrm{~s}$ & $v(\mathrm{C}-\mathrm{C})$ \\
\hline $1180 \mathrm{w}$ & $1178 \mathrm{w}$ & $1180 \mathrm{~m}$ & $1180 \mathrm{w}$ & $1178 \mathrm{sh}$ & \\
\hline $1086 \mathrm{~ms}$ & $1092 \mathrm{~s}$ & $1088 \mathrm{~s}$ & $1088 \mathrm{~s}$ & $1092 \mathrm{~s}$ & -CH; bending phenyl, \\
\hline $1010 \mathrm{~m}$ & $1011 \mathrm{~ms}$ & $1011 \mathrm{~m}$ & $1011 \mathrm{~m}$ & $1011 \mathrm{~m}$ & $v\left(\mathrm{SO}_{4}^{-2}\right)$ and \\
\hline $957 \mathrm{mbr}$ & $961 \mathrm{~m}$ & $957 \mathrm{w}$ & $956 \mathrm{~m}$ & $957 \mathrm{w}$ & $v_{\mathrm{s}}(\mathrm{N}-\mathrm{O}) ; \mathrm{NO}_{3}^{-}$ \\
\hline $818 \mathrm{~s}$ & $822 \mathrm{~s}$ & $822 \mathrm{~s}$ & $822 \mathrm{~s}$ & $822 \mathrm{~s}$ & \\
\hline $781 \mathrm{sh}$ & $789 \mathrm{sh}$ & $790 \mathrm{sh}$ & $783 \mathrm{w}$ & $787 \mathrm{w}$ & \\
\hline $717 \mathrm{w}$ & $725 \mathrm{~m}$ & $725 \mathrm{w}$ & $725 \mathrm{w}$ & $725 w$ & $v(\mathrm{M}-\mathrm{O}) ; v(\mathrm{M}-\mathrm{N})$ \\
\hline $681 \mathrm{vw}$ & $689 \mathrm{vw}$ & $689 \mathrm{sh}$ & $689 \mathrm{sh}$ & $689 \mathrm{sh}$ & ring deformation and \\
\hline $642 w$ & $645 \mathrm{~m}$ & $644 \mathrm{w}$ & $644 \mathrm{w}$ & $633 \mathrm{~m}$ & $\delta_{b}\left(\mathrm{SO}_{4}^{-2}\right)$ \\
\hline $560 \mathrm{~s}$ & 622 & 620 & 622 & $563 \mathrm{~m}$ & \\
\hline $502 \mathrm{~m}$ & $563 \mathrm{~s}$ & $563 \mathrm{~m}$ & $563 \mathrm{~m}$ & $502 \mathrm{w}$ & \\
\hline $453 \mathrm{mbr}$ & $505 \mathrm{~ms}$ & $502 \mathrm{~m}$ & $505 \mathrm{w}$ & $467 w$ & \\
\hline $437 \mathrm{w}$ & $467 \mathrm{~s}$ & $467 \mathrm{w}$ & $467 \mathrm{w}$ & $433 \mathrm{sh}$ & \\
\hline & $433 \mathrm{sh}$ & $433 \mathrm{sh}$ & $433 \mathrm{sh}$ & & \\
\hline
\end{tabular}

Key: $\mathrm{s}=$ strong, $\mathrm{w}=$ weak, $\mathrm{v}=$ very, $\mathrm{m}=$ medium, $\mathrm{br}=$ broad, $\mathrm{sh}=$ shoulder, $v=$ stretching, $\delta_{b}=$ bending.

\section{UV-Visible solid reflection spectra}

The formation of the ligand and its metal complexes was also confirmed by the electronic solid reflection spectra in the range 200-800 $\mathrm{nm}$ (Figure 2). The free ligand reflects at 208, 279, 322 and $344 \mathrm{~nm}$, respectively (Table 3 ) that may be attributed to $\pi-\pi^{*}$ and $n-\pi^{*}$ transitions which occur in unsaturated hydrocarbons containing ketonic groups [18]. On complexation, The 208 $\mathrm{nm}$ is absent besides a bathochromic shift of the $279,322 \mathrm{~nm}$ bands and the appearance of new reflections. The complexes have bands in the range from 518 to $522 \mathrm{~nm}$ which may be assigned to ligand to metal charge-transfer [19]. Also, the presence of new bands in the range of 569 to $682 \mathrm{~nm}$ in all complexes may be attributed to d-d transition. 

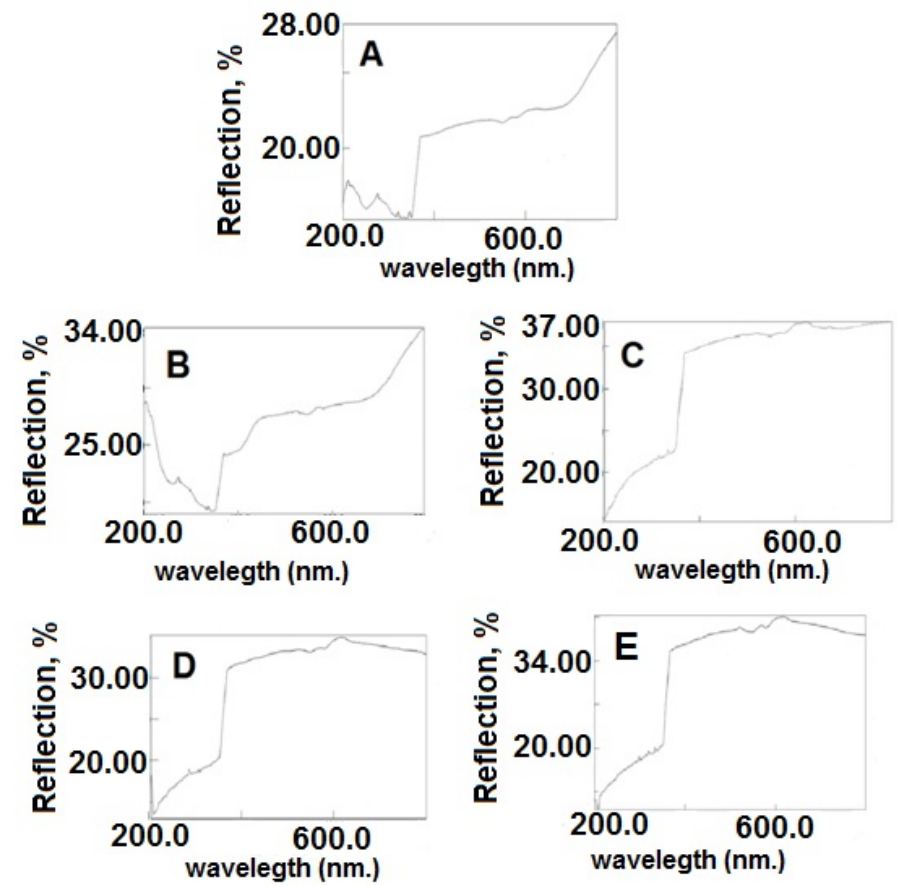

Figure 2. Electronic reflection spectra for (A) 4,6-bis (4-chlorophenyl)-2-oxo-1,2-dihydropyridine-3-carbinitrile (L), (B) $\left[\mathrm{Mn}(\mathrm{L})_{2}\left(\mathrm{H}_{2} \mathrm{O}\right)_{2}\right] \mathrm{SO}_{4}$, (C) $\left[\mathrm{Fe}(\mathrm{L})_{2}\left(\mathrm{H}_{2} \mathrm{O}\right)_{2}\right]\left(\mathrm{NO}_{3}\right)_{3}$, (D) $\left[\mathrm{Co}(\mathrm{L})_{2}\left(\mathrm{H}_{2} \mathrm{O}\right)_{2}\right] \mathrm{Cl}_{2}$ and $(\mathrm{E})\left[\mathrm{Ni}(\mathrm{L})_{2}\left(\mathrm{H}_{2} \mathrm{O}\right)_{2}\right] \mathrm{SO}_{4} \cdot 6 \mathrm{H}_{2} \mathrm{O}$.

Table 3. UV-Vis spectra of $L$ and its metal complexes.

\begin{tabular}{|c|c|c|c|c|c|}
\hline \multirow{2}{*}{ Assignments $(\mathrm{nm})$} & \multirow{2}{*}{$\mathrm{L}$} & \multicolumn{4}{|c|}{$\mathrm{L}_{2}$ complex with } \\
\cline { 3 - 6 } & 208 & $\mathrm{Mn}(\mathrm{II})$ & $\mathrm{Fe}(\mathrm{III})$ & $\mathrm{Co}(\mathrm{II})$ & $\mathrm{Ni}$ (II) \\
\hline$\pi-\pi^{*}$ transitions & 2082,344 & 271 & - & - & - \\
\hline $\mathrm{n}-\pi^{*}$ transitions & $279,327,336$ & 300 & $299,319,325$ \\
\hline Ligand-metal charge transfer & - & 518 & 519 & 522, & 522 \\
\hline $\mathrm{d}-\mathrm{d}$ transition & - & 571 & $569,620,672$ & $570,616,682$ & $570,616,661$ \\
\hline
\end{tabular}

\section{${ }^{1} H$ NMR spectra}

The formation of the metal complexes was also confirmed by ${ }^{1} \mathrm{H}$ NMR spectra (Figure 3 ). The ${ }^{1} \mathrm{H}$ NMR spectra for complexes exhibit new peaks in the range 3.17-3.39 ppm, (Table 4) due to the presence of water molecules in the complexes [1]. Also, the compounds showed peacks in the range $\delta$ : $12.85-12.93$ for $\mathrm{NH}$ amide and at 6.66-8.11 ppm for $-\mathrm{CH}$ aromatic. On comparing main peaks of free ligand with its complexes, it is observed that all the peaks of the free ligand are present in the spectra of the complexes with chemical shift upon binding of free ligand to the metal ion [20]. 


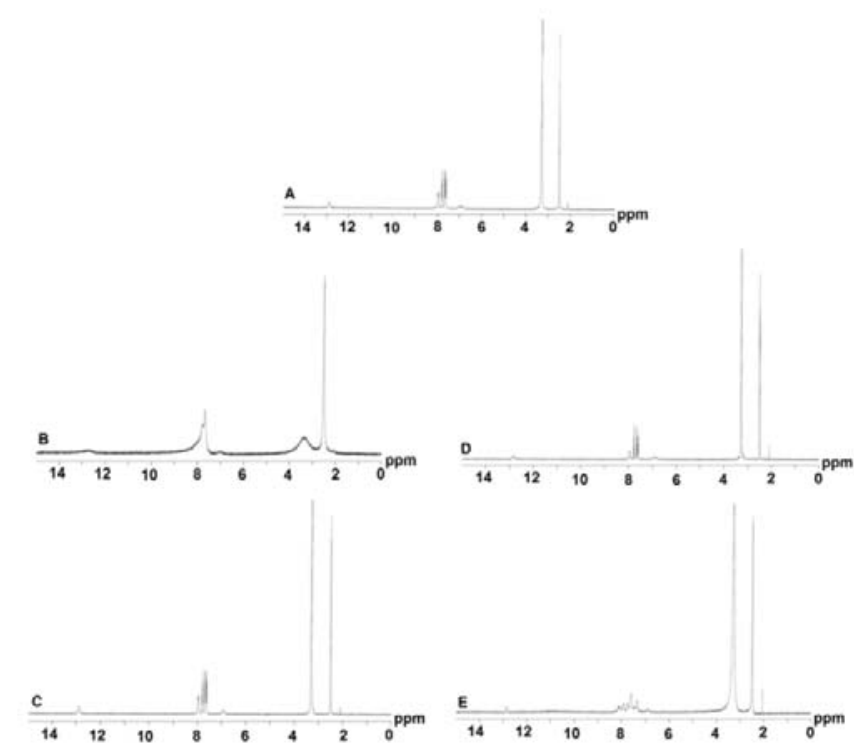

Figure 3. ${ }^{1} \mathrm{H}$ NMR spectra for (A) 4,6-bis (4-chlorophenyl)-2-oxo-1,2-dihydropyridine-3carbinitrile (L), (B) $\left[\mathrm{Mn}(\mathrm{L})_{2}\left(\mathrm{H}_{2} \mathrm{O}\right)_{2}\right] \mathrm{SO}_{4}, \quad$ (C) $\left[\mathrm{Fe}(\mathrm{L})_{2}\left(\mathrm{H}_{2} \mathrm{O}\right)_{2}\right]\left(\mathrm{NO}_{3}\right)_{3}$, $\left[\mathrm{Co}(\mathrm{L})_{2}\left(\mathrm{H}_{2} \mathrm{O}\right)_{2}\right] \mathrm{Cl}_{2}$ and $(\mathrm{E})\left[\mathrm{Ni}(\mathrm{L})_{2}\left(\mathrm{H}_{2} \mathrm{O}\right)_{2}\right] \mathrm{SO}_{4} \cdot 6 \mathrm{H}_{2} \mathrm{O}$.

Table 4. ${ }^{1} \mathrm{H}$ NMR values (ppm) and tentative assignments for (A) (L), (B) $\left[\mathrm{Mn}(\mathrm{L})_{2}\left(\mathrm{H}_{2} \mathrm{O}\right)_{2}\right] \mathrm{SO}_{4},(\mathrm{C})$ $\left[\mathrm{Fe}(\mathrm{L})_{2}\left(\mathrm{H}_{2} \mathrm{O}\right)_{2}\right]\left(\mathrm{NO}_{3}\right)_{3}$, (D) $\left[\mathrm{Co}(\mathrm{L})_{2}\left(\mathrm{H}_{2} \mathrm{O}\right)_{2}\right] \mathrm{Cl}_{2}$ and $(\mathrm{E})\left[\mathrm{Ni}(\mathrm{L})_{2}\left(\mathrm{H}_{2} \mathrm{O}\right)_{2}\right] \mathrm{SO}_{4} \cdot 6 \mathrm{H}_{2} \mathrm{O}$.

\begin{tabular}{|l|l|l|l|}
\hline A & - & $6.88-8.0$ & 12.90 \\
\hline B & 3.34 & $6.66-7.98$ & 12.85 \\
\hline C & 3.30 & $6.90-7.96$ & 12.93 \\
\hline D & $3.17-3.39$ & $6.83-7.93$ & 12.87 \\
\hline E & 3.30 & $6.90-8.11$ & 12.86 \\
\hline Assignments & $\delta \mathrm{H}, \mathrm{H}_{2} \mathrm{O}$ & $\delta \mathrm{H},-\mathrm{CH}$ aromatic & $\delta \mathrm{H},-\mathrm{NH}$ amide \\
\hline
\end{tabular}

Mass spectra

Mass spectrum of the free ligand (L) is in a good agreement with the suggested structure. The ligand $(\mathrm{L})$ showed molecular ion peak $\left(\mathrm{M}^{+}\right)$at $\mathrm{m} / \mathrm{z}=340(24 \%)$ and $\mathrm{M}^{+2}$ at $\mathrm{m} / \mathrm{z}=342(8 \%)$ (Figure 4). The molecular ion peak [a] losses $\mathrm{Cl}_{2}$ to give fragment [b] at $\mathrm{m} / \mathrm{z}=270(7 \%)$, also it losses $\mathrm{Cl}^{-}$to give fragment [c] at $\mathrm{m} / \mathrm{z}=305(11 \%)$, also it losses $\mathrm{CN}$ to give fragment [d] at $\mathrm{m} / \mathrm{z}$ $=314(8 \%)$ and it losses $\mathrm{O}^{-}, \mathrm{C}_{12} \mathrm{H}_{8} \mathrm{Cl}_{2} \mathrm{CN}$ and $\mathrm{C}_{12} \mathrm{H}_{8} \mathrm{Cl}_{2} \mathrm{O}$ to give fragment [e] at $\mathrm{m} / \mathrm{z}=324$ $(10 \%)$, [f] at $\mathrm{m} / \mathrm{z}=92(23 \%)$ and $[\mathrm{g}]$ at $\mathrm{m} / \mathrm{z}=86(35 \%)$. The molecular ion peak [a] losses $\mathrm{C}_{12} \mathrm{H}_{8} \mathrm{Cl}_{2}$ to give fragment $[\mathrm{h}]$ at $\mathrm{m} / \mathrm{z}=118(11 \%)$ and it also losses $\mathrm{C}_{6} \mathrm{H}_{4} \mathrm{CNCl}$ to give fragment [i] at $\mathrm{m} / \mathrm{z}=216(10 \%)$. It losses $\mathrm{C}_{6} \mathrm{H}_{4} \mathrm{Cl}$ to give [j] at $\mathrm{m} / \mathrm{z}=229(9 \%)$ and losses $\mathrm{C}_{6} \mathrm{H}_{4} \mathrm{ClO}$ to give fragment $[\mathrm{k}]$ at $\mathrm{m} / \mathrm{z}=213(23 \%)$ (Scheme 3$)$. The fragmentation patterns of our studied complexes were obtained from the mass spectra. The mass spectra of $\mathrm{Mn}(\mathrm{II}), \mathrm{Co}(\mathrm{II})$ and $\mathrm{Ni}(\mathrm{II})$ displayed molecular peak at $\mathrm{m} / \mathrm{z}=868(17 \%), 846(12 \%)$ and $980(29 \%)$, respectively, suggesting that the molecular weights of the assigned products matching with elemental and thermogravimetric analyses. Fragmentation pattern of the complex $\left[\mathrm{Fe}(\mathrm{L})_{2}\left(\mathrm{H}_{2} \mathrm{O}\right)_{2}\right]\left(\mathrm{NO}_{3}\right)_{3}$ is used as an example. The molecular ion peak [a] appeared at $\mathrm{m} / \mathrm{z}=957(32 \%)$ losses $\mathrm{C}_{24} \mathrm{H}_{16} \mathrm{Cl}_{4}$ to give 
Studies on 4,6-bis (4-chlorophenyl)-2-oxo-1,2-dihydropyridine-3-carbonitrile metal complexes 83

[b] at $\mathrm{m} / \mathrm{z}=513(22 \%)$ and it losses $\mathrm{C}_{24} \mathrm{H}_{16} \mathrm{Cl}_{4} \mathrm{NO}_{3}$ to give [c] at $\mathrm{m} / \mathrm{z}=451(13 \%)$. The molecular ion peak [a] losses $\left(\mathrm{NO}_{3}\right)_{3}$ to give [d] at $\mathrm{m} / \mathrm{z}=771(12 \%)$ and it losses $\mathrm{C}_{24} \mathrm{H}_{16} \mathrm{Cl}_{4}\left(\mathrm{NO}_{3}\right)_{2}$ to give [e] at $\mathrm{m} / \mathrm{z}=389(16 \%)$. The molecular ion peak [a] losses $\left(\mathrm{NO}_{3}\right)_{2}$ to give fragment [f] at $\mathrm{m} / \mathrm{z}=833(32 \%)$ and it losses $\mathrm{NO}_{3}$ to give fragment [g] at $\mathrm{m} / \mathrm{z}=895(11 \%)$. The molecular ion peak [a] losses $\mathrm{C}_{24} \mathrm{H}_{16} \mathrm{Cl}_{4}\left(\mathrm{NO}_{3}\right)_{3}$ to give fragment [h] at $\mathrm{m} / \mathrm{z}=327(16 \%)$ and it losses $\mathrm{C}_{12} \mathrm{H}_{8} \mathrm{Cl}_{2}\left(\mathrm{NO}_{3}\right)_{3}$ to give fragment [i] at $\mathrm{m} / \mathrm{z}=594(19 \%)$. The molecular ion peak [a] losses $2 \mathrm{Cl}_{2}$ to give fragment [j] at $\mathrm{m} / \mathrm{z}=817(11 \%)$, it losses $\mathrm{C}_{12} \mathrm{H}_{8} \mathrm{Cl}_{2}$ to give fragment [k] at $\mathrm{m} / \mathrm{z}=735(9 \%)$, it losses $\mathrm{Cl}_{2}$ to give fragment [1] at $\mathrm{m} / \mathrm{z}=887(17 \%)$ and it losses $\mathrm{C}_{12} \mathrm{H}_{8} \mathrm{Cl}_{2} \mathrm{NO}_{3}$ to give fragment $[\mathrm{m}]$ at $\mathrm{m} / \mathrm{z}=611(20 \%)$ (Scheme 4$)$.
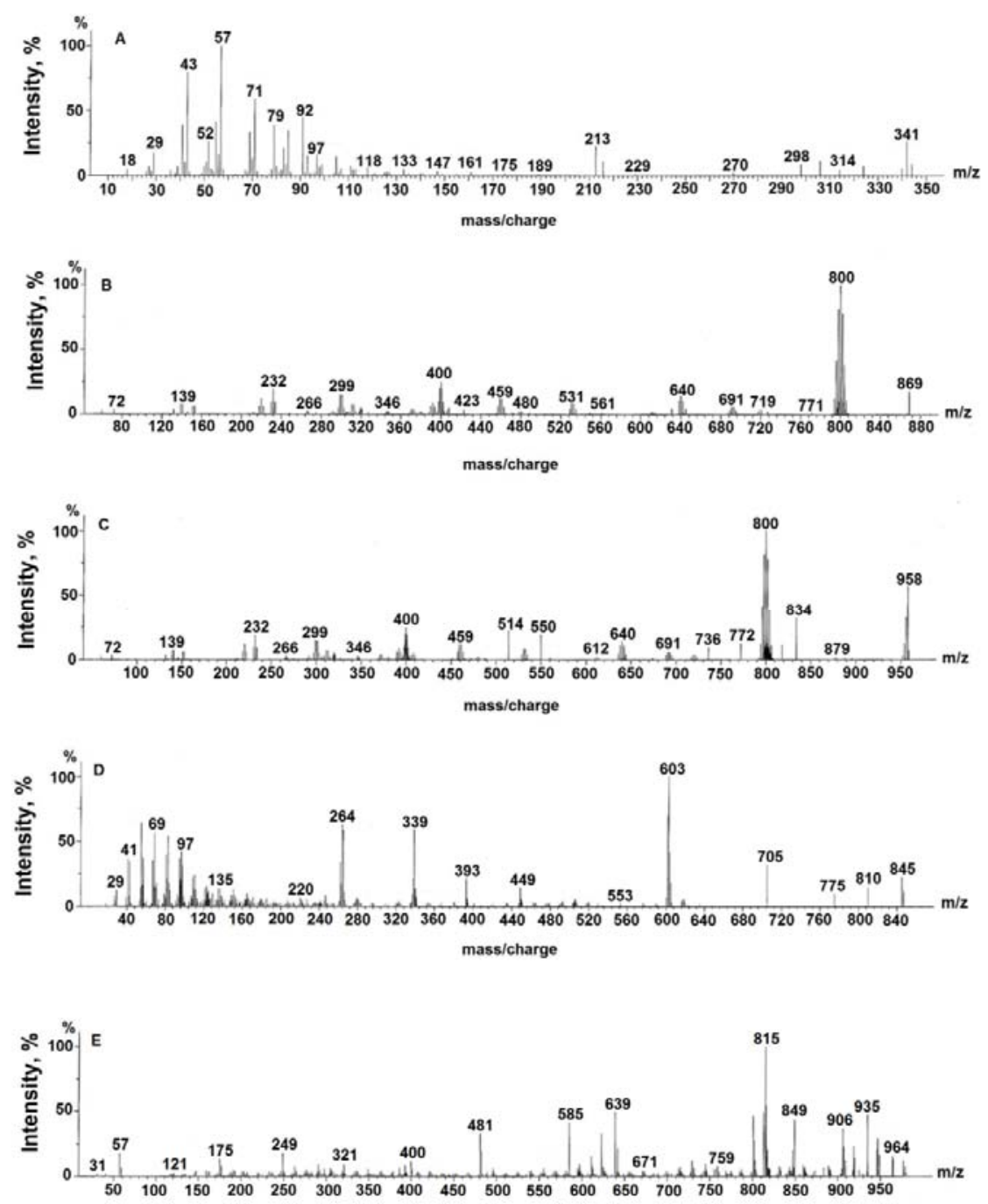

Figure 4. Mass spectra of (A) L, (B) $\left[\mathrm{Mn}(\mathrm{L})_{2}\left(\mathrm{H}_{2} \mathrm{O}\right)_{2}\right] \mathrm{SO}_{4},(\mathrm{C}) \quad\left[\mathrm{Fe}(\mathrm{L})_{2}\left(\mathrm{H}_{2} \mathrm{O}\right)_{2}\right]\left(\mathrm{NO}_{3}\right)_{3}$, (D) $\left[\mathrm{Co}(\mathrm{L})_{2}\left(\mathrm{H}_{2} \mathrm{O}\right)_{2}\right] \mathrm{Cl}_{2}$ and $(\mathrm{E})\left[\mathrm{Ni}(\mathrm{L})_{2}\left(\mathrm{H}_{2} \mathrm{O}\right)_{2}\right] \mathrm{SO}_{4} \cdot 6 \mathrm{H}_{2} \mathrm{O}$.

Bull. Chem. Soc. Ethiop. 2015, 29(1) 

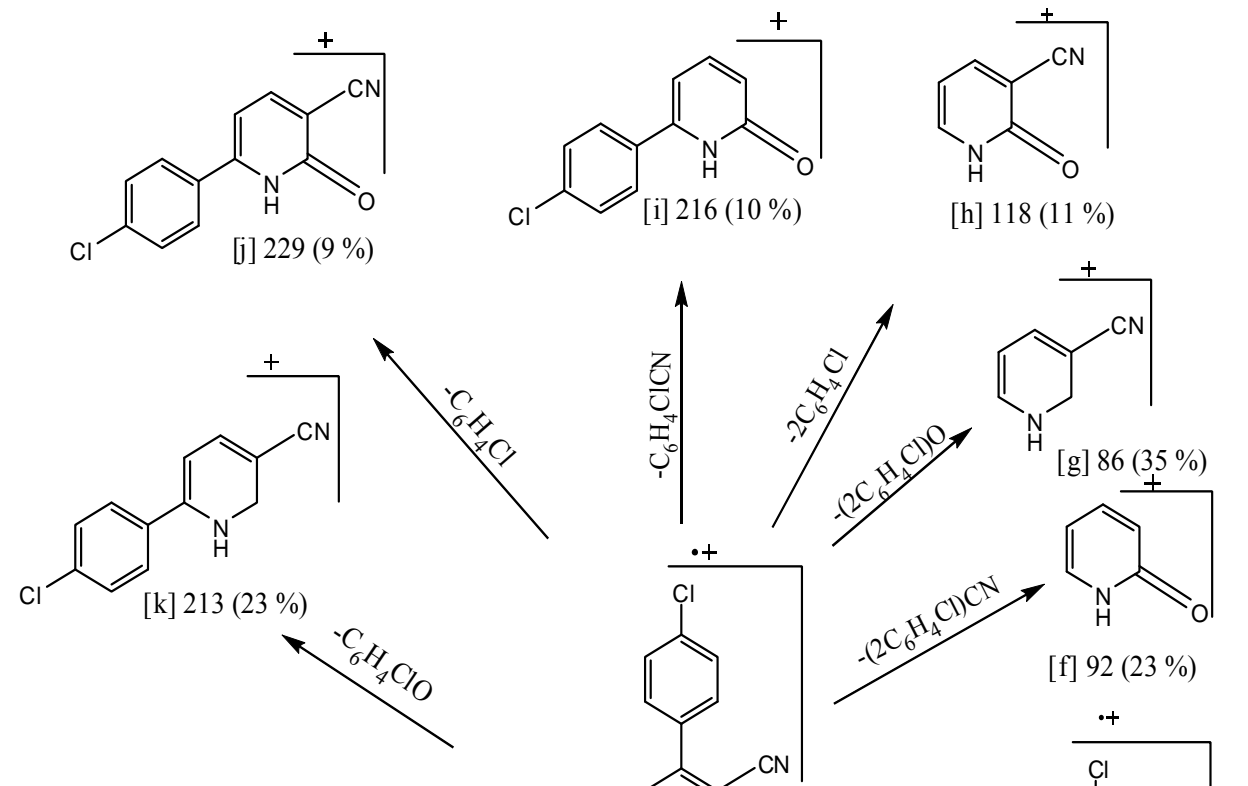<smiles>N#Cc1c(-c2ccccc2)cc(-c2ccccc2)[nH]c1=O</smiles>

[b] $270(7 \%)$

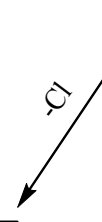<smiles>O=c1[nH]c(-c2ccc(Cl)cc2)cc(-c2ccccc2)c1Cl</smiles>

[c] $305(11 \%)$
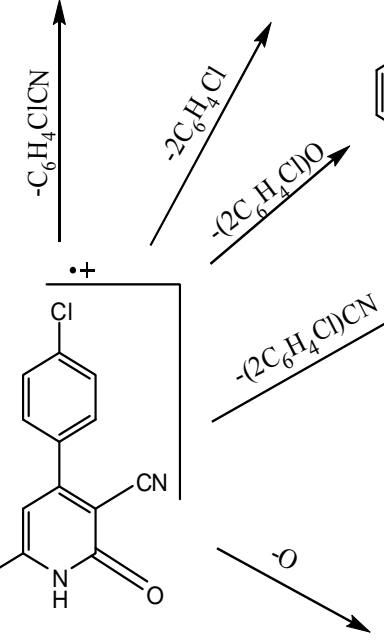

[a] $\mathrm{m} / \mathrm{z} 340(24 \%)$ $\mathrm{M}^{+2} 342(8 \%)$
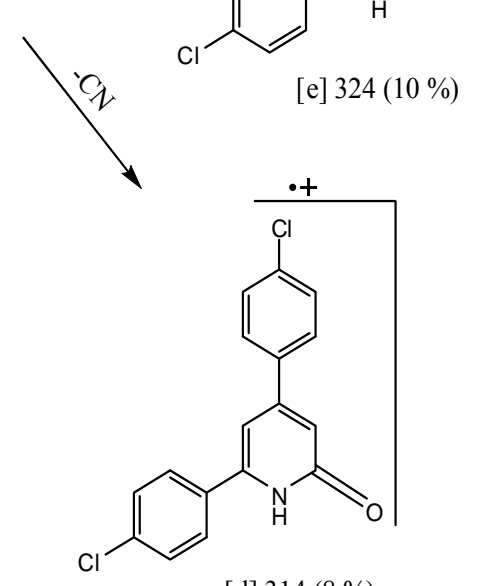

[d] $314(8 \%)$

Scheme 3. Fragmentation pattern of L.

Bull. Chem. Soc. Ethiop. 2015, 29(1) 
Studies on 4,6-bis (4-chlorophenyl)-2-oxo-1,2-dihydropyridine-3-carbonitrile metal complexes 85

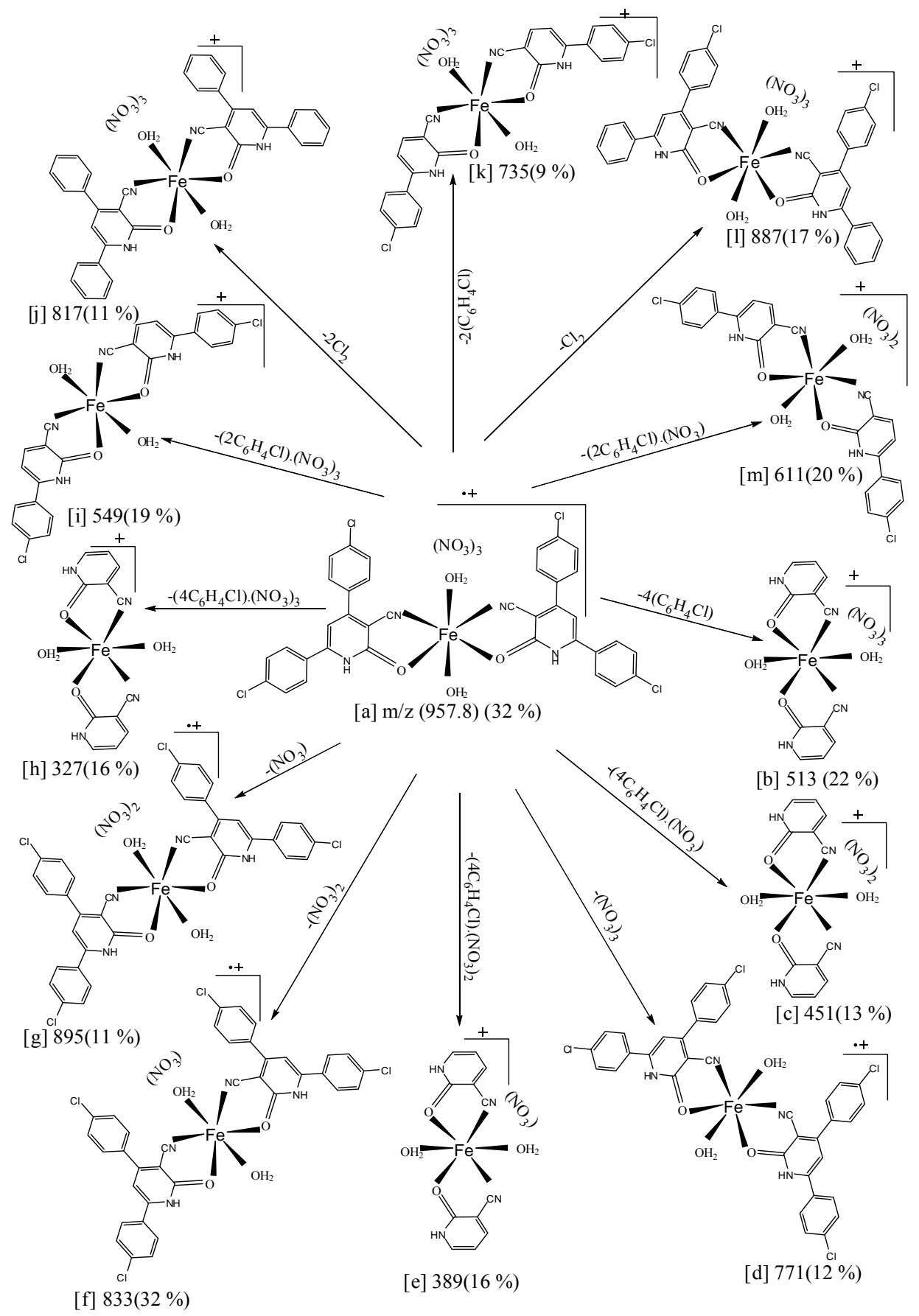

Scheme 4. Fragmentation pattern of $\left[\mathrm{Fe}(\mathrm{L})_{2}\left(\mathrm{H}_{2} \mathrm{O}\right)_{2}\right]\left(\mathrm{NO}_{3}\right)_{3}$.

Bull. Chem. Soc. Ethiop. 2015, 29(1) 
Thermal analysis

The 4,6-bis (4-chlorophenyl)-2-oxo-1,2-dihydropyridine-3-carbonitrile (L) of $\mathrm{Mn}$ (II), Fe(III), $\mathrm{Co}(\mathrm{II})$ and $\mathrm{Ni}(\mathrm{II})$ complexes are stable at room temperature and can be stored for several months without any changes. To establish the proposed formulae for the new complexes of Mn(II), $\mathrm{Fe}(\mathrm{III}), \mathrm{Co}$ (II) and $\mathrm{Ni}(\mathrm{II})$ under investigation, thermogravimetric (TGA) and differential thermogravimetric (DTG) analyses were carried out for the solid complexes under $\mathrm{N}_{2}$ flow from ambient temperature to $800{ }^{\circ} \mathrm{C}$ (Figure 5). Table 5 give the maximum temperature values, $\mathrm{T}_{\max } /{ }^{\circ} \mathrm{C}$ together with the corresponding weight loss for each step of the decomposition reactions of the above compounds. The obtained data strongly support the proposed chemical formulae of the compounds and indicated that the ligand ( $\mathrm{L}$ ) is thermally stable at room temperature. Decomposition of the $\mathrm{L}$ started at $350{ }^{\circ} \mathrm{C}$ and finished at $600{ }^{\circ} \mathrm{C}$ with one stage at maximum 411 ${ }^{\circ} \mathrm{C}$ and is accompanied by a weight loss of $82.50 \%$ corresponding to loss of five molecules of acetylene, one molecule of carbon monooxide and two molecule of cyanogen chloride [21].

The thermal decomposition of $\mathrm{Mn}(\mathrm{II}), \mathrm{Fe}(\mathrm{III})$ and $\mathrm{Co}(\mathrm{II})$ complexes proceed approximately with one main degradation step at 200 and $360{ }^{\circ} \mathrm{C}$ for $\mathrm{Mn}$ (II), at $320{ }^{\circ} \mathrm{C}$ for $\mathrm{Fe}(\mathrm{III})$ and at $502{ }^{\circ} \mathrm{C}$ for $\mathrm{Co}(\mathrm{II})$ leaving $\mathrm{MnSO}_{4}, \mathrm{Fe}_{2} \mathrm{O}_{3}$ and $\mathrm{CoO}$ as a final products (Table 5).

The TGA curve of $\left[\mathrm{Ni}(\mathrm{L})\left(\mathrm{H}_{2} \mathrm{O}\right)_{2}\right] \mathrm{SO}_{4} \cdot 6 \mathrm{H}_{2} \mathrm{O}$ shows two stages of decomposition. The first stage occurs at maximum temperature $80{ }^{\circ} \mathrm{C}$ corresponds to the loss of six water molecules with mass loss of $11.56 \%$ (calc. $11.01 \%$ ). The relatively low value of temperature of this step may indicated that these water molecules undergoes less H-bonding. The second step of decomposition occurs at two maxima at 337 and $451{ }^{\circ} \mathrm{C}$, is accompanied by a weight loss of $91.51 \%$ which leaving $\mathrm{NiO}+3 \mathrm{C}$, as resdue $[22,23]$.

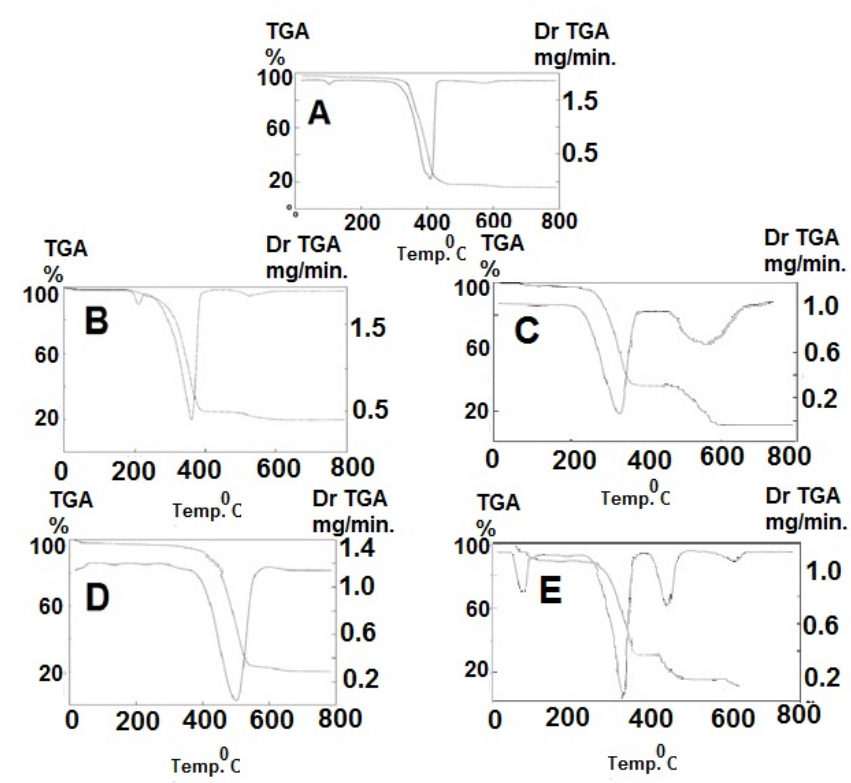

Figure 5. TGA and DTG curves of (A) 4,6-bis (4-chlorophenyl)-2-oxo-1,2-dihydropyridine-3carbinitrile (L), (B) $\left[\mathrm{Mn}(\mathrm{L})_{2}\left(\mathrm{H}_{2} \mathrm{O}\right)_{2}\right] \mathrm{SO}_{4}, \quad$ (C) $\left[\mathrm{Fe}(\mathrm{L})_{2}\left(\mathrm{H}_{2} \mathrm{O}\right)_{2}\right]\left(\mathrm{NO}_{3}\right)_{3}$, $\left[\mathrm{Co}(\mathrm{L})_{2}\left(\mathrm{H}_{2} \mathrm{O}\right)_{2}\right] \mathrm{Cl}_{2}$ and $(\mathrm{E})\left[\mathrm{Ni}(\mathrm{L})_{2}\left(\mathrm{H}_{2} \mathrm{O}\right)_{2}\right] \mathrm{SO}_{4} \cdot 6 \mathrm{H}_{2} \mathrm{O}$. 
Studies on 4,6-bis (4-chlorophenyl)-2-oxo-1,2-dihydropyridine-3-carbonitrile metal complexes 87

Table 5. The maximum temperature $\mathrm{T}_{\max }\left({ }^{\circ} \mathrm{C}\right)$ and weight loss values of the decomposition stages for $\mathrm{L}_{2}$, $\mathrm{Mn}(\mathrm{II}), \mathrm{Fe}(\mathrm{III}), \mathrm{Co}(\mathrm{II})$ and $\mathrm{Ni}(\mathrm{II})$.

\begin{tabular}{|c|c|c|c|c|c|}
\hline \multirow[t]{2}{*}{ Compounds } & \multirow[t]{2}{*}{ Decomposition } & \multirow[t]{2}{*}{$\mathrm{T}_{\max }\left({ }^{\circ} \mathrm{C}\right)$} & \multicolumn{2}{|c|}{ Weight loss (\%) } & \multirow[t]{2}{*}{ Lost species } \\
\hline & & & Calc. & Found & \\
\hline \multirow{3}{*}{$\begin{array}{c}(\mathrm{L}) \\
\left(\mathrm{C}_{18} \mathrm{H}_{10} \mathrm{~N}_{2} \mathrm{OCl}_{2}\right)\end{array}$} & First step & 411 & 82.50 & 82.50 & $5 \mathrm{C}_{2} \mathrm{H}_{2}+\mathrm{CO}+2 \mathrm{NCCl}$ \\
\hline & Total loss & & 82.50 & 82.50 & \\
\hline & Residue & & 17.50 & 17.50 & $5 \mathrm{C}$ \\
\hline \multirow{3}{*}{$\begin{array}{c}{\left[\mathrm{Mn}(\mathrm{L})_{2}\left(\mathrm{H}_{2} \mathrm{O}\right)_{2}\right] \mathrm{SO}_{4}} \\
\left(\mathrm{C}_{36} \mathrm{H}_{24} \mathrm{~N}_{4} \mathrm{O}_{8} \mathrm{Cl}_{4} \mathrm{SMn}\right)\end{array}$} & First step & 200,360 & 77.11 & 79.43 & $12 \mathrm{C}_{2} \mathrm{H}_{2}+4 \mathrm{CO}+4 \mathrm{NCCl}$ \\
\hline & Total loss & & 77.11 & 79.43 & \\
\hline & Residue & & 22.89 & 20.56 & $\mathrm{MnSO}_{4}+4 \mathrm{C}$ \\
\hline \multirow[t]{3}{*}{$\begin{array}{c}{\left[\mathrm{Fe}(\mathrm{L})_{2}\left(\mathrm{H}_{2} \mathrm{O}\right)_{2}\right]\left(\mathrm{NO}_{3}\right)_{3}} \\
\left(\mathrm{C}_{36} \mathrm{H}_{24} \mathrm{~N}_{7} \mathrm{O}_{13} \mathrm{Cl}_{4} \mathrm{Fe}\right)\end{array}$} & First step & 320 & 94.18 & 94.40 & $\begin{array}{c}11 \mathrm{C}_{2} \mathrm{H}_{2}+\mathrm{NO}+10 \mathrm{CO}+ \\
0.5 \mathrm{H}_{2} \mathrm{O}+4 \mathrm{NCCl}+0.5 \mathrm{H}_{2}\end{array}$ \\
\hline & Total loss & & 94.18 & 94.40 & \\
\hline & Residue & & 5.81 & 5.60 & $0.5 \mathrm{Fe}_{2} \mathrm{O}_{3}$ \\
\hline \multirow[t]{3}{*}{$\begin{array}{c}{\left[\mathrm{Co}(\mathrm{L})_{2}\left(\mathrm{H}_{2} \mathrm{O}\right)_{2}\right] \mathrm{Cl}_{2}} \\
\left(\mathrm{C}_{36} \mathrm{H}_{28} \mathrm{~N}_{4} \mathrm{O}_{6} \mathrm{Cl}_{6} \mathrm{Co}\right)\end{array}$} & First step & 502 & 82.65 & 82.50 & $\begin{array}{c}12 \mathrm{C}_{2} \mathrm{H}_{2}+0.5 \mathrm{~N}_{2}+3 \mathrm{CO}+ \\
1.5 \mathrm{Cl}_{2}+3 \mathrm{NCCl}\end{array}$ \\
\hline & Total loss & & 82.65 & 82.50 & \\
\hline & Residue & & 17.34 & 17.50 & $\mathrm{CoO}+6 \mathrm{C}$ \\
\hline \multirow{3}{*}{$\begin{array}{c}{\left[\mathrm{Ni}(\mathrm{L})_{2}\left(\mathrm{H}_{2} \mathrm{O}\right)_{2}\right] \mathrm{SO}_{4} .6 \mathrm{H}_{2} \mathrm{O}} \\
\left(\mathrm{C}_{36} \mathrm{H}_{30} \mathrm{~N}_{4} \mathrm{O}_{11} \mathrm{Cl}_{4} \mathrm{SNi}\right)\end{array}$} & First step & 80 & 11.01 & 11.65 & $6 \mathrm{H}_{2} \mathrm{O}$ \\
\hline & Second step & 337,451 & 80.56 & 79.95 & $12 \mathrm{C}_{2} \mathrm{H}_{2}+5 \mathrm{CO}+\mathrm{SO}_{2}+4 \mathrm{NCCl}$ \\
\hline & $\begin{array}{l}\text { Total loss, } \\
\text { Residue }\end{array}$ & & $\begin{array}{c}91.57 \\
8.43\end{array}$ & $\begin{array}{c}91.51 \\
8.49\end{array}$ & $\mathrm{NiO}+3 \mathrm{C}$ \\
\hline
\end{tabular}

Table 6. The inhibition diameter zone values $(\mathrm{mm})$ for $\left(\mathrm{L}_{2}\right)$ and its metal complexes.

\begin{tabular}{|c|c|c|c|c|c|c|c|}
\hline \multirow{3}{*}{\multicolumn{2}{|c|}{ Compounds }} & \multicolumn{6}{|c|}{ Microbial species } \\
\hline & & \multicolumn{4}{|c|}{ Bacteria } & \multicolumn{2}{|c|}{ Fungi } \\
\hline & & E. coli & P. aeruginosa & B. subtilis & S. aureus & C. albuicans & A. fumigates \\
\hline \multicolumn{2}{|c|}{$\left(\mathrm{L}_{2}\right)$} & $11 \pm 0.10$ & $9 \pm 0.33$ & $13 \pm 0.04$ & $15 \pm 0.07$ & $17 \pm 0.55$ & $18 \pm 0.08$ \\
\hline \multicolumn{2}{|c|}{$\mathrm{L}_{2} / \mathrm{Mn}(\mathrm{II})$} & $18^{+2} \pm 0.10$ & $17^{+2} \pm 0.33$ & $18^{+1} \pm 0.04$ & $19^{+1} \pm 0.07$ & $19^{\mathrm{NS}} \pm 0.55$ & $19^{\mathrm{NS}} \pm 0.08$ \\
\hline \multicolumn{2}{|c|}{$\mathrm{L}_{2} / \mathrm{Fe}(\mathrm{III})$} & $19^{+2} \pm 0.10$ & $19^{+3} \pm 0.33$ & $19^{+1} \pm 0.04$ & $20^{+1} \pm 0.07$ & $18^{\mathrm{NS}} \pm 0.55$ & $20^{\mathrm{NS}} \pm 0.08$ \\
\hline \multicolumn{2}{|c|}{$\mathrm{L}_{2} / \mathrm{Co}(\mathrm{II})$} & $20^{+2} \pm 0.10$ & $20^{+3} \pm 0.33$ & $21^{+2} \pm 0.04$ & $22^{+2} \pm 0.07$ & $20^{+1} \pm 0.55$ & $22^{+1} \pm 0.08$ \\
\hline \multicolumn{2}{|c|}{$\mathrm{L}_{2} / \mathrm{Ni}(\mathrm{II})$} & $19^{+2} \pm 0.10$ & $21^{+3} \pm 0.33$ & $20^{+2} \pm 0.04$ & $20^{+1} \pm 0.07$ & $21^{+1} \pm 0.55$ & $26^{+2} \pm 0.08$ \\
\hline \multicolumn{2}{|c|}{$\mathrm{Fe}\left(\mathrm{NO}_{3}\right)_{3} \cdot 9 \mathrm{H}_{2} \mathrm{O}$} & $10 \pm 0.33$ & $12 \pm 0.11$ & 0 & 0 & 0 & 0 \\
\hline \multicolumn{2}{|c|}{$\mathrm{CoCl}_{2} \cdot 6 \mathrm{H}_{2} \mathrm{O}$} & 0 & 0 & 0 & 0 & 0 & 0 \\
\hline \multicolumn{2}{|c|}{$\mathrm{NiSO}_{4} \cdot 6 \mathrm{H}_{2} \mathrm{O}$} & 0 & 0 & 0 & 0 & 0 & 0 \\
\hline \multicolumn{2}{|c|}{$\mathrm{MnSO}_{4} \cdot 6 \mathrm{H}_{2} \mathrm{O}$} & 0 & 0 & 0 & 0 & 0 & 0 \\
\hline \multicolumn{2}{|c|}{ Control (DMSO) } & 0 & 0 & 0 & 0 & 0 & 0 \\
\hline \multirow[t]{3}{*}{ Standard } & Ampicilin & 0 & 0 & $28 \pm 0.40$ & 0 & 0 & 0 \\
\hline & Amoxycilin & 0 & 0 & $22 \pm 0.11$ & $18 \pm 1.73$ & 0 & 0 \\
\hline & Cefaloxin & $24 \pm 0.34$ & 0 & $27 \pm 1.15$ & $16 \pm 0.52$ & 0 & 0 \\
\hline
\end{tabular}

ND: non-detectable. i.e., the inhibition zones exceed the plate diameter. Statistical significance $\mathrm{P}^{\mathrm{NS}} \mathrm{P}$ not significant, $\mathrm{P}>0.05 ; \mathrm{P}^{+1} \mathrm{P}$ significant, $\mathrm{P}<0.05 ; \mathrm{P}^{+2} \mathrm{P}$ highly significant, $\mathrm{P}<0.01 ; \mathrm{P}^{+3} \mathrm{P}$ very highly significant, $\mathrm{P}$ $<0.001$; student's-test (paired).

\section{Antimicrobial activity}

The efficiencies of $\mathrm{L}$ and their metal complexes have been investigated against two Gramnegative, Escherichia coli and Pseudomonas aeruginosa and two Gram-positive, Staphylococcus aureus and Bacillus subtilis also antifungal screening was studied against two species Aspergillus fumigatas and Candida albicans microorganisms. The results of the antibacterial study of $\mathrm{L}$ and their complexes (Table 6) have inhibitory action against all four 
types of bacteria and antifungal activity (Figure 6). The complexes of Mn(II) shows a highly significant against Escherichia coli and Pseudomonas aeruginosa and moderate activity against Bacillus subtilis, Staphylococcus aureus than free ligand. Fe(III) shows very highly significant against Pseudomonas aeruginosa, a highly significant against Escherichia coli and moderate significant against Gram-positive. The Co(II) shows very high significant against Pseudomonas aeruginosa and highly significant against Escherichia coli, Staphylococcus aureus and Bacillus subtilis and moderate significant for antifungal species. For Ni(II) complex shows very highly significant against Pseudomonas aeruginosa but, for Escherichia coli, Bacillus subtilis and Aspergillus fumigates are highly significant and moderate significant against Staphylococcus aureus and Candida albicans. The nature of the metal ion coordinated to a drug may have a significant role to this diversity. In general for metal complexes showing antimicrobial activity, the following five principal factors $[13,14]$ should be considered: i) the chelate effect; ii) the nature of the ligands; iii) the total charge of the complex; iv) the nature of the ion neutralizing the ionic complex; and v) the nuclearity of the metal center in the complex.

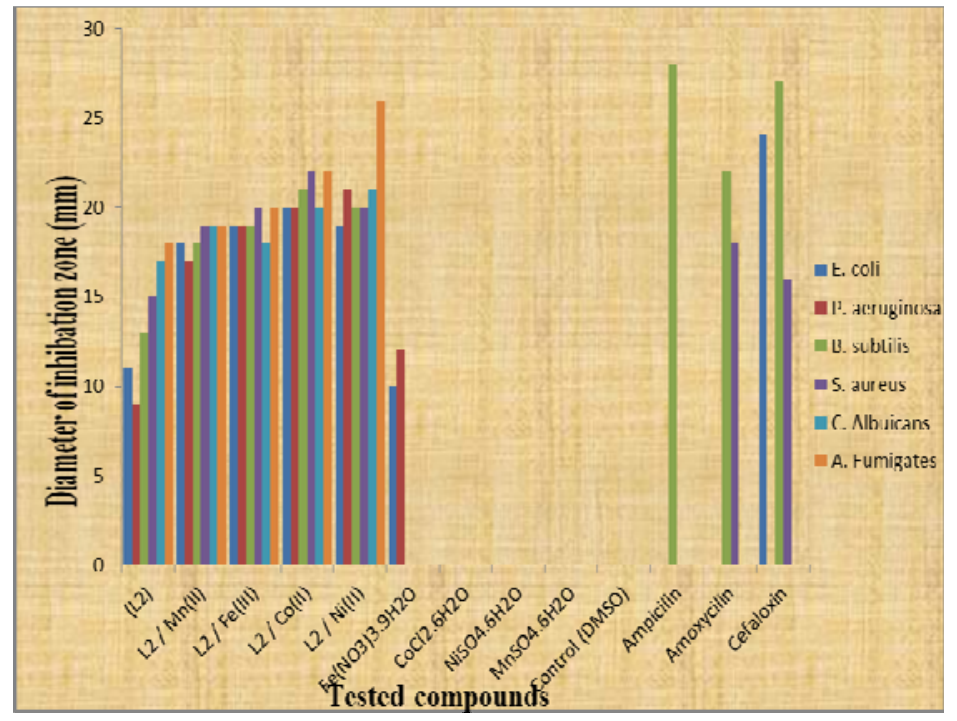

Figure 6. Statistical representation for biological activity of $\left(\mathrm{L}_{2}\right)$ and its metal complexes.

Computational details

\section{Computational method}

The geometric parameters and energies were computed by DFT at the B3LYP/CEP-31G level, using the GAUSSIAN 98W package of the programs, on geometries that were optimized at CEP-31G basis set. The high basis set was chosen to detect the energies at a highly accurate level. The atomic charges were computed using the natural atomic orbital populations. The B3LYP is the keyword for the hybrid functional, [24], which is a linear combination of the gradient functional proposed by Becke [25] and Lee et al. [26] together with the Hartree-Fock local exchange function [27]. 
Structural parameters and models

(4,6)bis-4-chlorophenyle-2-oxo-1,2-dihydropyridine-3-carbonitrile (L)

The biological activity of pyridinones $\mathrm{L}$ is mainly determined by its fine structure, the $\mathrm{L}$ has many characteristic structural features. The molecule is not highly sterically-hindered, the two benzene rings in the same plane of the pyridinone ring. This observation is supported by the values of calculated dihedral angles of $\mathrm{C} 3 \mathrm{C} 4 \mathrm{C} 5 \mathrm{C} 8$ and $\mathrm{C} 6 \mathrm{C} 5 \mathrm{C} 8 \mathrm{C} 9$ are $180.00^{\circ}$ and $0.00^{\circ}$ (Table 7) while the dihedral angles of $\mathrm{C} 11 \mathrm{C} 17 \mathrm{C} 21 \mathrm{C} 22$ and $\mathrm{C} 11 \mathrm{C} 17 \mathrm{C} 18 \mathrm{C} 19$ are $180.00^{\circ}$ and $180.00^{\circ}$. Scheme 5 shows the optimized geometrical structure of $\mathrm{L}$ molecule, the dihedral angles of $\mathrm{N} 16 \mathrm{C} 15 \mathrm{C} 9 \mathrm{C} 13$ and $\mathrm{N} 16 \mathrm{C} 15 \mathrm{C} 9 \mathrm{C} 8$ are $0.00^{\circ}$ and $180.00^{\circ}$ which confirms $-\mathrm{CN}$ group in the same plane of molecule.

The bond distance of $\mathrm{C} 13-\mathrm{O} 14$ is $1.289 \AA$ and the bond angle of $\mathrm{C} 9 \mathrm{C} 15 \mathrm{~N} 16$ is $164.29^{\circ}$ reflects on sp hybridization of $\mathrm{C} 15$ and the bond length of $\mathrm{C} 15 \mathrm{~N} 16$ is $1.208 \AA$. The values of bond distances are compared nicely with that obtained from experimental data [28].

There is a significant built up of charge density on oxygen atom and two nitrogen atoms of pyridinone and cyano group, so L is bi-dentate ligand (O14 and N16 atoms) and the molecule is not highly dipole $\mu=7.37$ because the planarity of L molecule. The charge accumulated on $\mathrm{Cl} 7$ and $\mathrm{Cl} 23$ are -0.287 and -0.277 , respectively, also, the charge on N12 and N16 are -0.218 and -0.258 , respectively. The total energy of the optimized geometry of L molecule is -191.782 au. The metal ligand binding, dipole moment, total energy and optimized geometrical structure of all complexes were studied and the DFT of Mn(II) complex is used as example in my article.

Table 7. Equilibrium geometric parameters bond lengths $(\AA)$, bond angles $\left({ }^{\circ}\right)$, dihedral angles $\left({ }^{\circ}\right)$ and charge density of $(4,6)$ bis-4-chlorophenyle-2-oxo-1,2-dihydropyridine-3-carbinitrile ligand by using DFT/B3LYP/Cep-31G.

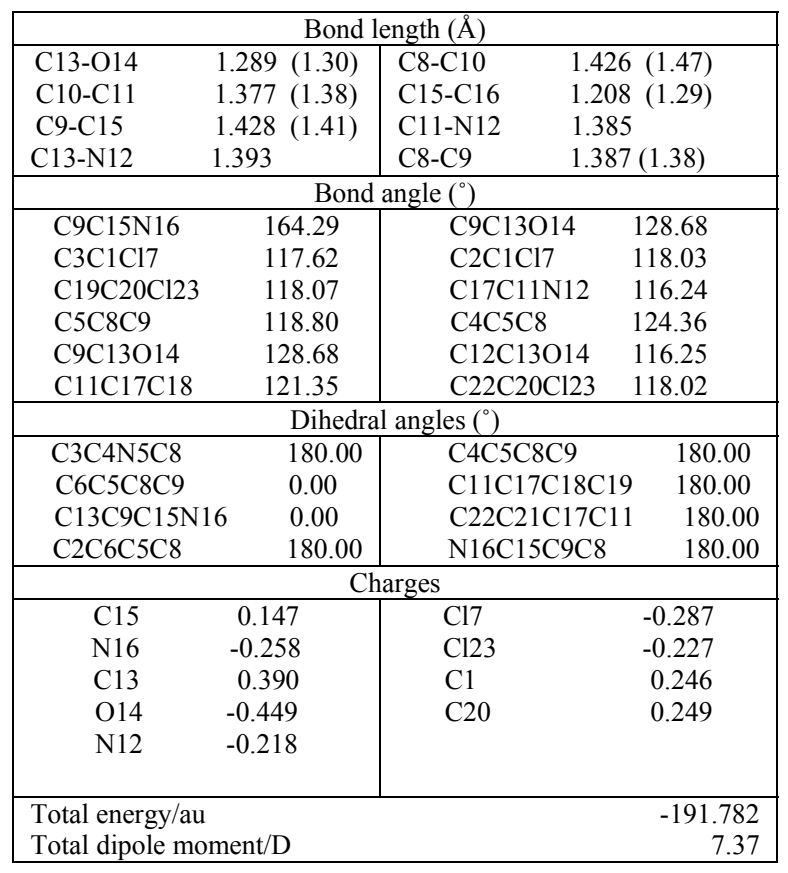




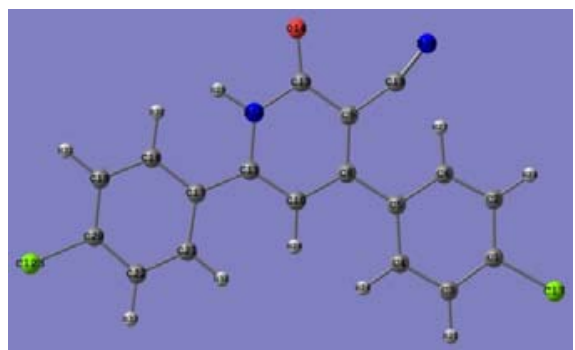

Scheme 5. The optimized geometrical structure of L by using B3LYP/CEP-31G.

The Mn(II) L complexes

$\mathrm{Mn}$ (II) binds two molecules of $\mathrm{L}$ through two oxygen and two nitrogen atoms of $\mathrm{L}$. The complex is six-coordinate with four coordinate bonds from two $\mathrm{L}$ molecules and water or sulfate. We studied $\left[\mathrm{Mn}(\mathrm{L})_{2}\left(\mathrm{SO}_{4}\right)\right]$ and $\left[\mathrm{Mn}(\mathrm{L})_{2}\left(\mathrm{H}_{2} \mathrm{O}\right)_{2}\right]^{2+}$.

Description of the structure of $\left[\mathrm{Mn}(\mathrm{L})_{2}\left(\mathrm{SO}_{4}\right)\right]$

The structure of complex with atomic numbering scheme is shown in Scheme 6. The complex is six-coordinate with distorted octahedral environment around the metal ion. The Mn(II) is coordinated through two oxygen and two nitrogen atoms of two ligand and two oxygen atoms of $\mathrm{SO}_{4}{ }^{-2}$ group. The Mn-O25 and Mn-O33 bond lengths are $2.026 \AA$ and $2.025 \AA$, respectively [29, 30]. The Mn-N27 and Mn-N29 are $1.795 \AA$ and $1.796 \AA$, respectively, (Table 8) and the bond distance between $\mathrm{Mn}-\mathrm{O} 2$ and $\mathrm{Mn}-\mathrm{O} 3$ of sulfate group are $1.849 \AA$ and $1.849 \AA$, respectively [31]. Also, the angles around the Mn (II) with surrounding four oxygen atoms and two nitrogen atoms vary from $73.46^{\circ}$ to $172.31^{\circ}$; these values differ legally from these expected for a regular octahedron.

The energy of this complex is -434.252 au while the dipole moment is lower than free ligand $4.425 \mathrm{D}$ also, the charge accumulated on $\mathrm{O} 25$ and N27 of the first molecule are -0.396 and -0.179 , respectively. $\mathrm{O} 33$ and $\mathrm{N} 29$ of the second molecule are -0.386 and -0.193 , respectively. The bond angle of $\mathrm{O} 4 \mathrm{SO} 5$ of sulfate group is $130.76^{\circ}$ [32].

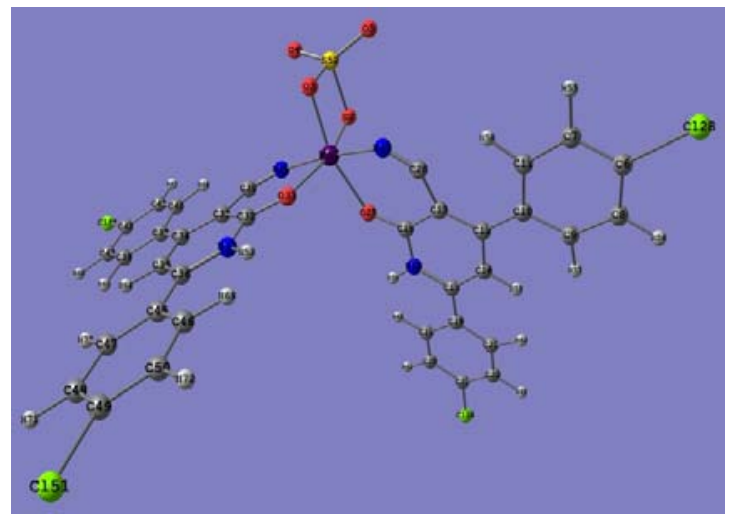

Scheme 6. Optimized geometrical structure of $\left[\mathrm{Mn}(\mathrm{L})_{2}\left(\mathrm{SO}_{4}\right)\right]$ complex by using B3LYP/CEP$31 \mathrm{G}$. 
Studies on 4,6-bis (4-chlorophenyl)-2-oxo-1,2-dihydropyridine-3-carbonitrile metal complexes 91

Table 8. Equilibrium geometric parameters bond lengths $(\AA)$, bond angles $\left({ }^{\circ}\right)$ and charge density of [Mn $\left.\left(\mathrm{C}_{18} \mathrm{H}_{10} \mathrm{~N}_{2} \mathrm{OCl}_{2}\right)_{2}\left(\mathrm{SO}_{4}\right)\right]$ by using DFT/B3LYP/Cep-31G.

\begin{tabular}{|c|c|c|c|}
\hline \multicolumn{4}{|c|}{ Bond length $(\AA)$} \\
\hline $\mathrm{Mn}-\mathrm{O} 25$ & 2.016 & $\mathrm{C} 15-\mathrm{O} 25$ & 1.253 \\
\hline Mn-N27 & 1.795 & C32-O33 & 1.253 \\
\hline $\mathrm{Mn}-\mathrm{O} 33$ & 2.015 & $\mathrm{C} 26-\mathrm{N} 27$ & 1.145 \\
\hline Mn-N29 & 1.796 & C30-N29 & 1.145 \\
\hline $\mathrm{Mn}-\mathrm{O} 2$ & 1.849 & $\mathrm{~S}-\mathrm{O} 2$ & 1.652 \\
\hline $\mathrm{Mn}-\mathrm{O} 3$ & 1.849 & $\mathrm{~S}-\mathrm{O} 3$ & 1.651 \\
\hline \multicolumn{4}{|c|}{ Bond angle $\left({ }^{\circ}\right)$} \\
\hline O25 Mn N27 & 73.46 & $\mathrm{O} 25 \mathrm{Mn} \mathrm{O} 33$ & 96.07 \\
\hline O25 Mn N29 & 102.27 & N27 Mn N29 & 172.31 \\
\hline O3 Mn N27 & 90.74 & O2 Mn N29 & 91.52 \\
\hline $\mathrm{O} 2 \mathrm{Mn} \mathrm{O} 3$ & 77.14 & O3 Mn O33 & 95.80 \\
\hline O3 Mn N29 & 94.42 & $\mathrm{O} 25 \mathrm{Mn} \mathrm{O} 3$ & 161.71 \\
\hline $\mathrm{O} 2 \mathrm{Mn} \mathrm{O} 25$ & 94.81 & $\mathrm{O} 2 \mathrm{Mn}$ N27 & 95.19 \\
\hline N27 Mn O33 & 100.34 & $\mathrm{O} 2 \mathrm{Mn} \mathrm{O} 33$ & 163.06 \\
\hline & & N29 Mn O33 & 73.48 \\
\hline \multicolumn{4}{|c|}{ Charges } \\
\hline $\mathrm{Mn}$ & 0.343 & $\mathrm{O} 2$ & -0.353 \\
\hline $\mathrm{O} 25$ & -0.396 & $\mathrm{O} 3$ & -0.302 \\
\hline N27 & -0.179 & $\mathrm{C} 15$ & 0.466 \\
\hline O33 & -0.386 & C32 & 0.468 \\
\hline $\mathrm{N} 29$ & -0.193 & & \\
\hline Total energy/au & & & -434.252 \\
\hline Total dipole mo & ent/D & & 4.425 \\
\hline
\end{tabular}

Description of the structure of $\left[\mathrm{Mn}\left(\mathrm{L}_{2}\left(\mathrm{H}_{2} \mathrm{O}\right)_{2}\right]^{2+}\right.$

The structure of complex with atomic numbering scheme is shown in Scheme 7. The complex consists of two units of $\mathrm{L}$ molecule and two water molecules with $\mathrm{Mn}(\mathrm{II})$. The complex is sixcoordinate with distorted octahedral environment around the metal ion. The $\mathrm{Mn}$ (II) is coordinated to one $\mathrm{O}_{\text {keto }}$ atom and one $\mathrm{N}_{\text {car }}$ atom of L ligand and two oxygen atoms for water. The total energy of this complex is obtained by using density functional theory combined with $\mathrm{B} 3 \mathrm{LYP} / \mathrm{CEP}-31 \mathrm{G}$ as basis set. The bond angle between $\mathrm{O} 22 \mathrm{MnO} 30$ is 96.07 and also the angle between N24MnN26 is $164.18^{\circ}$ (Table 9) so the two L molecules are not lying in the same plane they are perpendicular respect to each other with angle equal $90^{\circ}$. The angle between $\mathrm{O} 2 \mathrm{MnO} 49$ is $91.04^{\circ}$ this value reflects that the two water molecules not in trans-form respect to each other but they are lying in cis-form and then they are perpendicular to each other.

The bond length between Mn-O30 and Mn-O22 are $2.026 \AA$ and $2.025 \AA$ are longer than that Mn-N26 and Mn-N24 (1.799 $\AA$ and $1.800 \AA)$ [29-31], while the bond distance between Mn$\mathrm{O}_{\mathrm{H} 2 \mathrm{O}}$ vary from $1.845 \AA$ and $1.846 \AA[32,33]$. Also, the angles around $\mathrm{Mn}(\mathrm{II})$ with surrounding oxygen atoms vary from $73.44^{\circ}$ to $166.15^{\circ}$; these values agree with these expected for a distorted octahedron.

The bond distances between $\mathrm{Mn}(\mathrm{II})$ and surrounded oxygen atoms and nitrogen atoms of $\mathrm{L}$ in water complex are shorter than that in sulfate complex. Also, the charge accumulated on $\mathrm{O}_{\text {keto }}$ $(-0.396$ and -0.386$)$ and $\mathrm{N}_{\mathrm{car}}(-0.179$ and -0.193$)$, in sulfate complex while, $\mathrm{O}_{\text {keto }}(-0.415$ and $-0.421)$ and $\mathrm{N}_{\text {car }}(-0.207$ and -0.205$)$, in water complex. There is a strong interaction between Mn (II) which become has charge equal +0.546 in case of water complex while, in case of sulphate complex the charge accumulated on $\mathrm{Mn}$ (II) is 0.343 . The energy of the water complex is more negative than sulfate complexes -474.816 au and relatively weak dipole $7.425 \mathrm{D}$. For all these reasons the water complex is more stable than other complexes and $\mathrm{Mn}$ (II) favor 
coordinated with two molecules of water more than one molecule of sulfate ion to complete the octahedron structure.

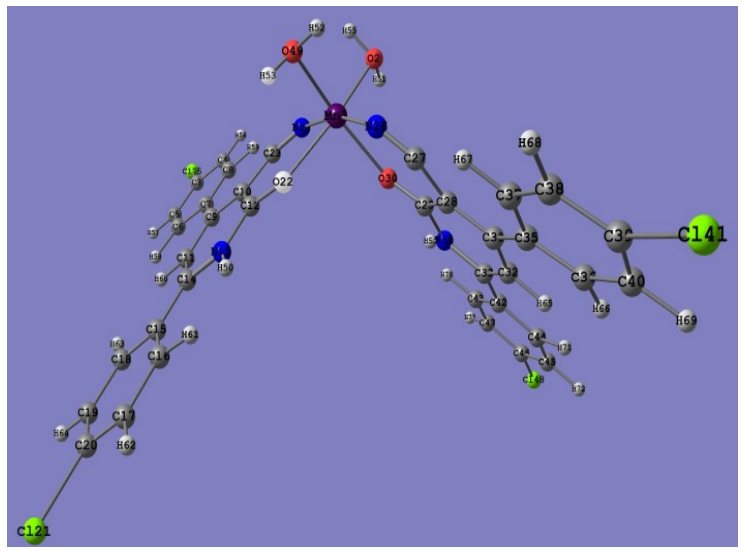

Scheme 7. Optimized geometrical structure of $\left[\mathrm{Mn}(\mathrm{L})_{2}\left(\mathrm{H}_{2} \mathrm{O}\right)_{2}\right]^{2+}$ complex by using B3LYP/CEP-31G.

Table 9. Equilibrium geometric parameters bond lengths $(\AA)$, bond angles $\left(^{\circ}\right)$ and charge density of [Mn $\left.\left(\mathrm{C}_{18} \mathrm{H}_{10} \mathrm{~N}_{2} \mathrm{OCl}_{2}\right)_{2}\left(\mathrm{H}_{2} \mathrm{O}\right)_{2}\right]^{2+}$ by using DFT/B3LYP/Cep-31G.

\begin{tabular}{|c|c|c|c|}
\hline \multicolumn{4}{|c|}{ Bond length $(\AA)$} \\
\hline $\mathrm{Mn}-\mathrm{O} 30$ & 2.026 & $\mathrm{C} 29-\mathrm{O} 30$ & 1.253 \\
\hline Mn-N24 & 1.80 & $\mathrm{C} 12-\mathrm{O} 22$ & 1.252 \\
\hline $\mathrm{Mn}-\mathrm{O} 22$ & 2.025 & C29-N34 & 1.363 \\
\hline Mn-N26 & 1.799 & $\mathrm{C} 23-\mathrm{N} 24$ & 1.146 \\
\hline $\mathrm{Mn}-\mathrm{O} 2$ & 1.845 & C29-C28 & 1.378 \\
\hline $\mathrm{Mn}-\mathrm{O} 49$ & 1.846 & $\mathrm{C} 10-\mathrm{C} 12$ & 1.378 \\
\hline \multicolumn{4}{|c|}{ Bond angle $\left({ }^{\circ}\right)$} \\
\hline O30 Mn N26 & 73.49 & $\mathrm{O} 20 \mathrm{Mn} \mathrm{O} 2$ & 91.05 \\
\hline O49 Mn N26 & 91.42 & $\mathrm{O} 22 \mathrm{Mn} \mathrm{O} 2$ & 166.15 \\
\hline O30 Mn N24 & 96.26 & N24 Mn O49 & 98.57 \\
\hline O22 Mn N24 & 73.44 & N26 Mn O22 & 94.42 \\
\hline N24 Mn O2 & 92.74 & $\mathrm{O} 30 \mathrm{Mn} \mathrm{O} 22$ & 91.33 \\
\hline N26 Mn N24 & 164.18 & O30 Mn O49 & 164.91 \\
\hline \multirow[t]{2}{*}{ N26 Mn O2 } & 99.35 & O22 Mn O49 & 90.12 \\
\hline & & $\mathrm{O} 2 \mathrm{Mn} \mathrm{O} 49$ & 91.05 \\
\hline \multicolumn{4}{|c|}{ Charges } \\
\hline $\mathrm{Mn}$ & 0.546 & $\mathrm{O} 2$ & -0.325 \\
\hline $\mathrm{O} 30$ & -0.421 & O49 & -0.333 \\
\hline $\mathrm{N} 26$ & -0.205 & $\mathrm{C} 29$ & 0.453 \\
\hline $\mathrm{O} 22$ & -0.415 & $\mathrm{C} 12$ & 0.454 \\
\hline $\mathrm{N} 24$ & -0.207 & & \\
\hline \multicolumn{2}{|c|}{ Total energy/au } & \multicolumn{2}{|r|}{-474.816} \\
\hline \multicolumn{2}{|c|}{ Total dipole moment/D } & & 7.425 \\
\hline
\end{tabular}


Studies on 4,6-bis (4-chlorophenyl)-2-oxo-1,2-dihydropyridine-3-carbonitrile metal complexes 93

\section{REFERENCES}

1. Rashad, A.E.; Shamroukh, A.H.; El-Hashash, M.A.; El-Farargy, A.F.; Yousif, N.M.; Salama, M.A.; Mostafa, A.; El-Shahat, M. J. Heterocycl. Chem. 2012, 49, 1130.

2. Katritzky, A.R.; Taylor, R. Adv. Heterocycl. Chem. 1990, 47, 308.

3. Jasinski, J.P.; Butcher, R.J.; Narayana, B.; Veena, K.; Yathirajan, H.S. Acta Cryst. 2009, E65, 2641.

4. Zordok, W.A.; Sadeek, S.A.; EL-Shwiniy, W.H. J. Coord. Chem. 2012, 65, 353.

5. Frisch, M.J.; Trucks, G.W.; Schlegel, H.B.; Scuseria, G.E.; Robb, M.A.; Cheeseman, J.R.; Zakrzewski, V.G.; Montgomery, J.A.; Stratmann, R.E.; Burant, J.C.; Dapprich, S.; Millam, J.M.; Daniels, A.D.; Kudin, K.N.; Strain, M.C.; Farkas, O.; Tomasi, J.; Barone, V.; Cossi, M.; Cammi, R.; Mennucci, B.; Pomelli, C.; Adamo, C.; Clifford, S.; Ochterski, J.; Petersson, G.A.; Ayala, P.Y.; Cui, Q.; Morokuma, K.; Malick, D.K.; Rabuck, A.D.; Raghavachari, K.; Foresman, J.B.; Cioslowski, J.; Ortiz, J.V.; Stefanov, B.B.; Liu, G.; Liashenko, A.; Piskorz, P.; Komaromi, I.; Gomperts, R.; Martin, R.L.; Fox, D.J.; Keith, T.; Al-Laham, M.A.; Peng, C.Y.; Nanayakkara, A.; Gonzalez, C.; Challacombe, M.; Gill, P.M.W.; Johnson, B.; Chen, W.; Wong, M.W.; Andres, J.L.; Gonzalez, C.; Head-Gordon, M.; Replogle, E.S.; Pople, J.A. Gaussian 98, Revision A.6, Gaussian, Inc. : Pittsburgh PA; 1998.

6. Stevens, W.J.; Krauss, M.; Bosch, H.; Jasien, P.G. Can. J. Chem. 1992, 70, 612.

7. Vogel, A.I.; Tatchell, A.R.; Furnis, B.S.; Hannaford, A.J.; Smith, P.W.G. Vogel Textbook of Practical Organic Chemistry, Prentice Hall: London; 1996; pp 88-90.

8. Beecher, D.J.; Wong, A.C. Appl. Environ. Microbial. 1994, 60, 1646.

9. Fallik, E.; Klein, J.; Grinberg, S.; Lomaniee, C.E.; Lurie, S.; Lalazar, A. J. Econ. Entomol. 1993, 77, 985.

10. Geary, W.J. Coord. Chem. Rev. 1971, 7, 81.

11. King, D.E.; Malone, R.; Lilley, S.H. Am. Fam. Phys. 2000, 61, 2741.

12. Nakamoto, K. Infrared and Raman Spectra of Inorganic and Coordination Compounds, 4th ed., Wiley: New York; 1988, pp 139, 141.

13. Nour, E.M.; Taha, A.A.; Anaimi, I.S. Inorg. Chem. Acta 1988, 139, 141.

14. Syamal, A.; Singhal, P.O.; Banerjee, S. Synth. React. Inorg. Met.-Org. Chem. 1980, 10, 243.

15. Efthimiadou, E.K.; Katsarou, M.; Sanakis, Y.; Raptopoulou, C.P.; Karaliota, A.; Katsaros, N.; Psomas, G. J. Inorg. Biochem. 2006, 100, 1378.

16. Zordok, W.A.; EL-Shwiniy, W.H.; EL-Attar, M.S.; Sadeek, S.A. J. Mol. Struct. 2013, 1047, 267.

17. Turel, I. Coord. Chem. Rev. 2002, 27, 232.

18. Nakamoto, K.; Mccarthy, P.J.; Fujiwara, S.; Shimura, Y.; Fujita, J.; Hare, C.R.; Saito, Y. Spectroscopy and Structure of Metal Chelate Compounds, John Wiley and Sons: New York; 1968.

19. Cotton, F.A.; Wilkinson, G.; Murillo, C.A.; Bochmann, M. Advanced Inorganic Chemistry, 6th ed., Wiley: New York; 1999.

20. Skauge, T.; Turel, I.; Sletten, E. Inorg. Chem. Acta 2002, 247, 339.

21. David, L.R. Handbook of Chemistry and Physics, 87th ed., CRC Press: United Kingdom; 2006.

22. Tagawa, H. Thermochim. Acta 1984, 80, 23.

23. Poston, J.A.; Ranjani, V.; Siriwadane, Edward, Fisher, P.; Angela, Miltz, L. App. Surf. Sci. 2003, $214,83$.

24. Kohn, W.; Sham, L.J. Phys. Rev A 1965, 140, 1133.

25. Becke, A.D. Phys. Rev. A 1988, 38, 3098

26. Lee, C.; Yang, W.; Parr, R.G. Phys. Rev B 1988, 37, 785.

27. Flurry Jr., R.L. Molecular Orbital Theory of Bonding in Organic Molecules, Marcel Dekker: New York; 1968. 
28. Turel, I.; Golic, L.; Bukovec, P.; Gubina, M. J. Inorg. Biochem. 1998, 71, 53.

29. Becker, T.M.; Krause Bauer, J.A.; Homrighausen, C.L.; Orchin, M. J. Organomet. Chem. 2000, 602, 97.

30. Schlieife, F.; Rodenstein, A.; Kirmse, R.; Kersting, B. Inorg. Chim. Acta 2011, 374, 521.

31. Kajnakova, M.; Cernak, J.; Kavecansky, V.; Gerared, F.; Papageorgiou, T.; Orendac, M.; Orendacova, A.; feher, A. Sol. Stat. Sci. 2006, 8, 203.

32. Gudasi, K.B.; Patil, S.A.; Vadavi, R.S.; Shenoy, R.V.; Nethaji, M.; Bligh, S.W.A. Inorg. Chem. Acta 2006, 359, 3229.

33. Bermejo, M.R.; Fondo, M.; García-Deibe, A.; González, A.M.; Sousa, A.; Sanmartín, J.; McAuliffe, C.A.; Pritchard, R.G.; Watkinson, M.; Lukov,V. Inorg. Chem. Acta 1999, 293, 210. 